Prepared in cooperation with the U.S. Department of Energy, National Nuclear Security Administration Nevada Site Office under Interagency Agreement DE-NA0001654

\title{
A Process to Estimate Net Infiltration Using a Site-Scale Water-Budget Approach, Rainier Mesa, Nevada National Security Site, Nevada, 2002-05
}

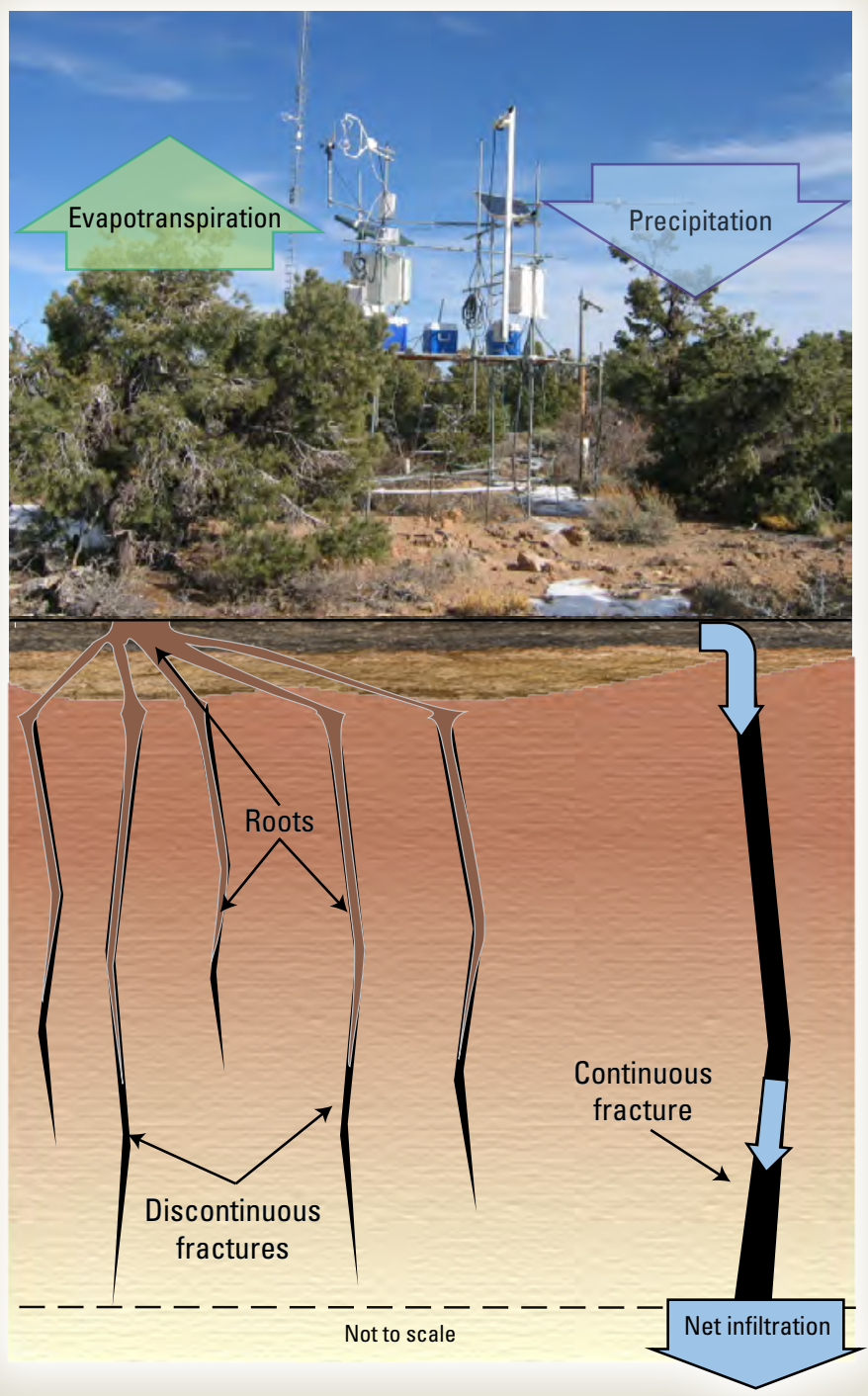

Scientific-Investigations Report 2017-5078 
Cover: Conceptual diagram of near-surface hydrologic processes, Rainier Mesa, Nevada National Security Site, Nevada. 


\section{A Process to Estimate Net Infiltration Using a Site-Scale Water-Budget Approach, Rainier Mesa, Nevada National Security Site, Nevada, 2002-05}

By David W. Smith, Michael T. Moreo, C. Amanda Garcia, Keith J. Halford, and Joseph M. Fenelon

Prepared in cooperation with the U.S. Department of Energy, National Nuclear Security Administration Nevada Site Office under Interagency Agreement DE-NA0001654

Scientific Investigations Report 2017-5078 


\title{
U.S. Department of the Interior \\ RYAN K. ZINKE, Secretary
}

\section{U.S. Geological Survey William H. Werkheiser, Acting Director}

\author{
U.S. Geological Survey, Reston, Virginia: 2017
}

For more information on the USGS - the Federal source for science about the Earth, its natural and living resources, natural hazards, and the environment-visit https://www.usgs.gov or call 1-888-ASK-USGS.

For an overview of USGS information products, including maps, imagery, and publications,

visit https://store.usgs.gov.

Any use of trade, firm, or product names is for descriptive purposes only and does not imply endorsement by the U.S. Government.

Although this information product, for the most part, is in the public domain, it also may contain copyrighted materials as noted in the text. Permission to reproduce copyrighted items must be secured from the copyright owner.

Suggested citation:

Smith, D.W., Moreo, M.T., Garcia, C.A., Halford, K.J., and Fenelon, J.M., 2017, A process to estimate net infiltration using a site-scale water-budget approach, Rainier Mesa, Nevada National Security Site, Nevada, 2002-05: U.S.

Geological Survey Scientific Investigations Report 2017-5078, 22 p., https://doi.org/10.3133/sir20175078.

ISSN 2328-0328 (online) 


\section{Contents}

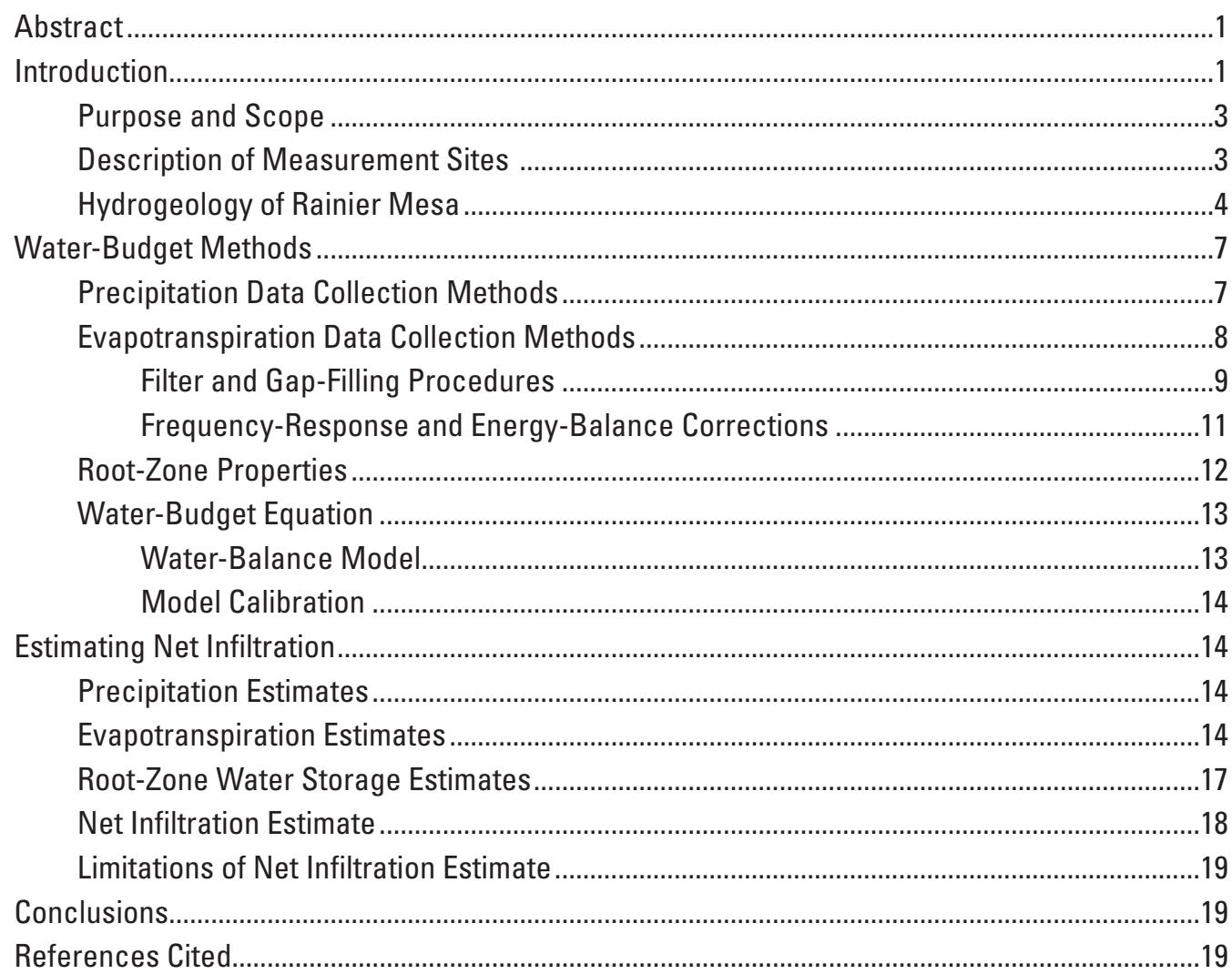




\section{Figures}

1. Map showing locations of U.S. Geological Survey evapotranspiration stations, selected National Oceanic and Atmospheric Administration weather stations, and selected groundwater monitoring wells, Rainier Mesa, Nevada National Security Site, Nevada

2. Photographs showing evapotranspiration sites $A 12$ weather and pinyon-juniper ET stations, and scrub-brush ET station, Rainier Mesa, Nevada National Security Site, Nevada

3. Photograph and conceptual diagram showing near-surface hydrologic processes, Rainier Mesa, Nevada National Security Site, Nevada

4. Hydrographs for selected monitoring wells, Rainier Mesa, Nevada National Security Site, Nevada, 1995-2015

5. Schematic showing flow of data filter and gap-filling processes for latent-heat flux, sensible-heat flux, and net radiation time-series data, Rainier Mesa, Nevada National Security Site, 2002-05.

6. Graph showing annual precipitation corrected for gage-catch deficiencies, Rainer Mesa, Nevada National Security Site, Nevada, July 1, 1959-June 30, 2015

7. Graphs showing daily corrected evapotranspiration (ET) and precipitation and soil-zone water storage at the pinyon-juniper and scrub-brush ET sites, Rainier Mesa, Nevada National Security Site, Nevada, January 1, 2002, to August 24, 2005.....16

8. Graphs showing water-balance model simulation results for pinyon-juniper evapotranspiration site, Rainier Mesa, Nevada National Security Site, 2002-05 .18

\section{Tables}

1. Location and general description of measurement sites, Rainier Mesa, Nevada National Security Site, Nevada, 2002-05.

2. Percentage of missing or filtered 20-minute net radiation, latent-heat flux, and sensible-heat flux data at the pinyon-juniper and scrub-brush evapotranspiration sites, Rainier Mesa, Nevada National Security Site, July 1, 2002-June 30, 2005.

3. Annual energy-balance fluxes and ratios at the pinyon-juniper and scrub-brush evapotranspiration sites, Rainier Mesa, Nevada National Security Site, Nevada, July 1, 2002-June 30, 2005

4. Root-zone properties including available water capacity and maximum water storage estimated at the pinyon-juniper and scrub-brush evapotranspiration sites,

Rainier Mesa, Nevada National Security Site, Nevada

5. Annual precipitation measured at $\mathrm{A} 12$ weather station, precipitation corrected for gage-catch deficiencies, and precipitation uncertainty estimated for pinyon-juniper and scrub-brush evapotranspiration sites, Rainier Mesa, Nevada National Security Site, Nevada, July 1, 2002-June 30, 2005

6. Annual evapotranspiration and uncertainty estimated for the pinyon-juniper and scrub-brush evapotranspiration sites, Rainier Mesa, Nevada National Security Site, Nevada, July 1, 2002-June 30, 2005.

7. Annual water budgets estimated for the pinyon-juniper and scrub-brush evapotranspiration sites, Rainier Mesa, Nevada National Security Site, Nevada, July 1, 2002-June 30, 2005 


\section{Conversion Factors}

International System of Units to U.S. customary units

\begin{tabular}{|c|c|c|}
\hline Multiply & By & To obtain \\
\hline \multicolumn{3}{|c|}{ Length } \\
\hline centimeter (cm) & 0.3937 & inch (in.) \\
\hline millimeter (mm) & 0.03937 & inch (in.) \\
\hline meter $(\mathrm{m})$ & 3.281 & foot $(\mathrm{ft})$ \\
\hline kilometer (km) & 0.6214 & mile (mi) \\
\hline \multicolumn{3}{|c|}{ Evaporation rate, wind speed } \\
\hline millimeter per year (mm/yr) & 0.03937 & inch per year (in/yr) \\
\hline meter per second $(\mathrm{m} / \mathrm{s})$ & 283465 & foot per day (ft/d) \\
\hline meter per second (m/s) & 2.2369 & mile per hour (mi/h) \\
\hline \multicolumn{3}{|c|}{ Volume } \\
\hline cubic meter $\left(\mathrm{m}^{3}\right)$ & 264.2 & gallon (gal) \\
\hline cubic meter $\left(\mathrm{m}^{3}\right)$ & 0.0002642 & million gallons (Mgal) \\
\hline cubic centimeter $\left(\mathrm{cm}^{3}\right)$ & 0.06102 & cubic inch $\left(\mathrm{in}^{3}\right)$ \\
\hline liter $(\mathrm{L})$ & 61.02 & cubic inch $\left(\mathrm{in}^{3}\right)$ \\
\hline cubic meter $\left(\mathrm{m}^{3}\right)$ & 35.31 & cubic foot $\left(\mathrm{ft}^{3}\right)$ \\
\hline cubic meter $\left(\mathrm{m}^{3}\right)$ & 1.308 & cubic yard $\left(\mathrm{yd}^{3}\right)$ \\
\hline cubic meter $\left(\mathrm{m}^{3}\right)$ & 0.0008107 & acre-foot (acre-ft) \\
\hline cubic hectometer $\left(\mathrm{hm}^{3}\right)$ & 810.7 & acre-foot (acre-ft) \\
\hline \multicolumn{3}{|c|}{ Pressure } \\
\hline kilopascal (kPa) & 0.145 & pound per square inch $\left(\mathrm{lb} / \mathrm{ft}^{2}\right)$ \\
\hline \multicolumn{3}{|c|}{ Density } \\
\hline grams per cubic meter $\left(\mathrm{g} / \mathrm{m}^{3}\right)$ & 0.00169 & pounds per cubic yard (lb/yd³) \\
\hline kilograms per cubic meter $\left(\mathrm{kg} / \mathrm{m}^{3}\right)$ & 0.06243 & pounds per cubic foot $\left(\mathrm{lb} / \mathrm{ft}^{3}\right)$ \\
\hline \multicolumn{3}{|c|}{ Hydraulic conductivity } \\
\hline meter per day $\left(\mathrm{m} \mathrm{d}^{-1}\right)$ & 3.281 & foot per day $\left(\mathrm{ft} \mathrm{d}^{-1}\right)$ \\
\hline \multicolumn{3}{|c|}{ Heat flux and specific heat } \\
\hline joule $(\mathrm{J})$ & 0.2390057 & calorie \\
\hline joules per gram (J/g) & 6.7756986 & calories per ounce \\
\hline $\begin{array}{l}\text { watt per square meter } \\
\qquad\left(\mathrm{W} / \mathrm{m}^{2}\right)\end{array}$ & 0.0002048 & $\begin{array}{l}\text { calorie per second per square foot } \\
{\left[(\mathrm{cal} / \mathrm{s}) / \mathrm{ft}^{2}\right]}\end{array}$ \\
\hline $\begin{array}{l}\text { Joules per kilogram per degrees } \\
\text { Celsius }\left[(\mathrm{J} / \mathrm{kg}) /{ }^{\circ} \mathrm{C}\right]\end{array}$ & 0.0002388 & $\begin{array}{l}\text { calorie per gram per degrees } \\
\text { Celsius }\left[(\mathrm{cal} / \mathrm{g}) /{ }^{\circ} \mathrm{C}\right]\end{array}$ \\
\hline
\end{tabular}

Temperature in degrees Celsius $\left({ }^{\circ} \mathrm{C}\right)$ may be converted to degrees Fahrenheit $\left({ }^{\circ} \mathrm{F}\right)$ as follows:

${ }^{\circ} \mathrm{F}=\left(1.8 x^{\circ} \mathrm{C}\right)+32$.

\section{Datums}

Vertical coordinate information is referenced to North American Vertical Datum of 1988

(NAVD 88).

Horizontal coordinate information is referenced to North American Datum of 1983 (NAD 83).

Altitude, as used in this report, refers to distance above the vertical datum. 



\title{
A Process to Estimate Net Infiltration Using a Site-Scale Water-Budget Approach, Rainier Mesa, Nevada National Security Site, Nevada, 2002-05
}

\author{
By David W. Smith, Michael T. Moreo, C. Amanda Garcia, Keith J. Halford, and Joseph M. Fenelon
}

\section{Abstract}

This report documents a process used to estimate net infiltration from precipitation, evapotranspiration (ET), and soil data acquired at two sites on Rainier Mesa. Rainier Mesa is a groundwater recharge area within the Nevada National Security Site where recharged water flows through bedrock fractures to a deep (450 meters) water table. The U.S. Geological Survey operated two ET stations on Rainier Mesa from 2002 to 2005 at sites characterized by pinyon-juniper and scrub-brush vegetative cover. Precipitation and ET data were corrected to remove measurement biases and gap-filled to develop continuous datasets. Net infiltration (percolation below the root zone) and changes in root-zone water storage were estimated using a monthly water-balance model.

Site-scale water-budget results indicate that the heavily-fractured welded-tuff bedrock underlying thin ( $<40$ centimeters) topsoil is a critical water source for vegetation during dry periods. Annual precipitation during the study period ranged from fourth lowest (182 millimeters $[\mathrm{mm}])$ to second highest $(708 \mathrm{~mm})$ on record (record $=55$ years). Annual ET exceeded precipitation during dry years, indicating that the fractured-bedrock reservoir capacity is sufficient to meet atmospheric-evaporative demands and to sustain vegetation through extended dry periods. Net infiltration $(82 \mathrm{~mm})$ was simulated during the wet year after the reservoir was rapidly filled to capacity. These results support previous conclusions that preferential fracture flow was induced, resulting in an episodic recharge pulse that was detected in nearby monitoring wells. The occurrence of net infiltration only during the wet year is consistent with detections of water-level rises in nearby monitoring wells that occur only following wet years.

\section{Introduction}

Rainier Mesa is a high volcanic plateau in the northcentral part of the Nevada National Security Site (NNSS) where 61 underground nuclear tests were done between 1957 and 1992 (U.S. Department of Energy, 2015). Recharge to the water table beneath Rainier Mesa occurs as precipitation that infiltrates through fractured bedrock and percolates downward to depths beyond the influence of evapotranspiration (ET) (Fenelon and others, 2008). The transport of radionuclides from test areas to regional aquifers is of concern to the U.S. Department of Energy and Nevada Division of Environmental Protection (U.S. Department of Energy, 2004). A better understanding of infiltration and deep percolation processes is needed to better assess recharge processes on Rainier Mesa and the potential for radionuclide migration to the regional groundwater flow system.

The U.S. Geological Survey (USGS) operated two ET stations on Rainier Mesa from January 2002 to August 2005 (DeMeo and others, 2006; fig. 1). The purpose of these ET stations was to collect data that could help better understand and characterize groundwater recharge processes; however, the usefulness of these data was limited because data corrections commonly applied today were not applied at the time of data collection and because there were multiple gaps in the datasets. Accurate and continuous ET and precipitation datasets are needed to develop accurate water budgets that can be used to estimate deep percolation and groundwater recharge. This report was done in cooperation with the U.S. Department of Energy to correct and gap-fill existing ET datasets and develop processes to estimate net infiltration on Rainier Mesa. 


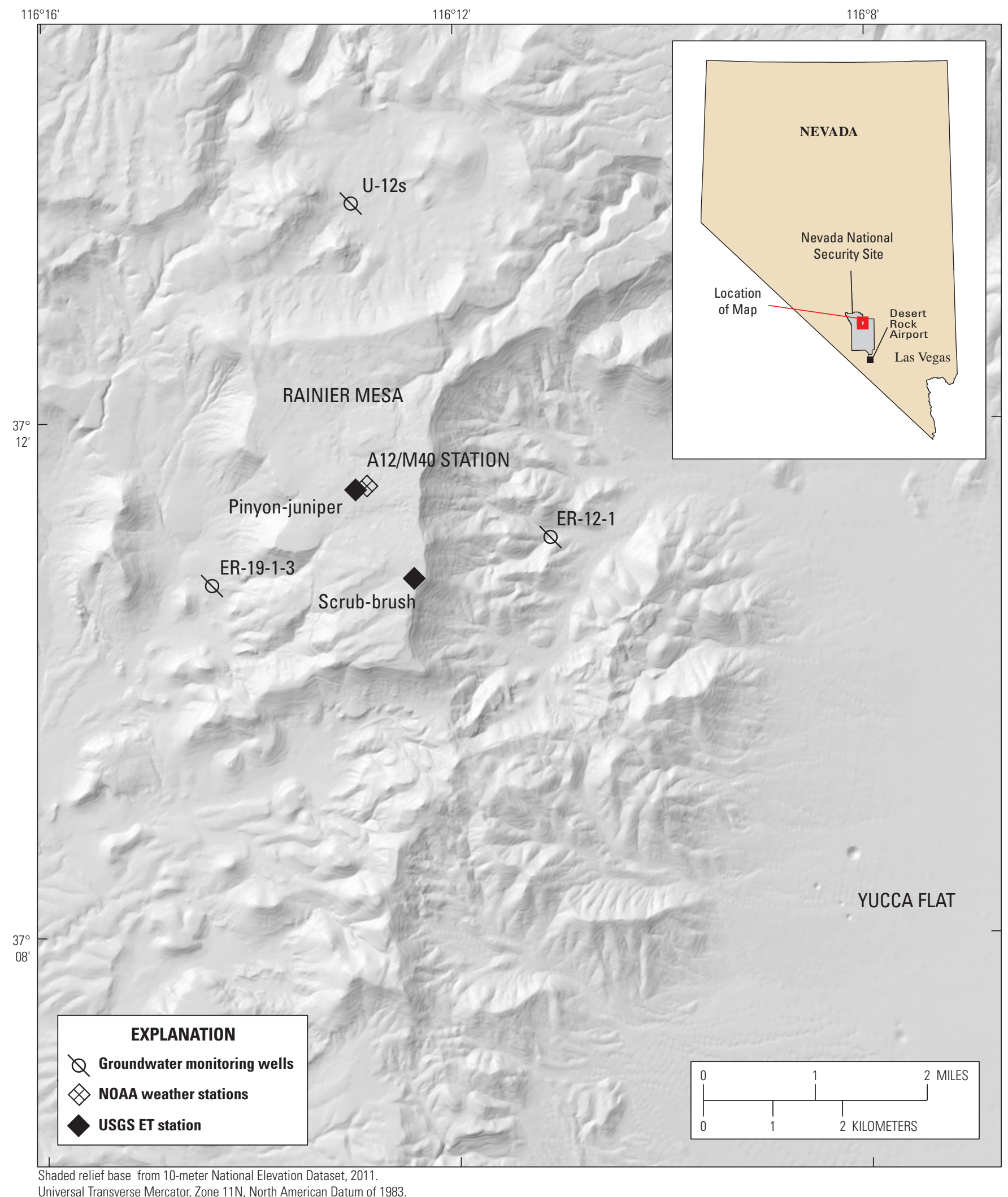

Figure 1. Locations of U.S. Geological Survey (USGS) evapotranspiration (ET) stations, selected National Oceanic and Atmospheric Administration (NOAA) weather stations, and selected groundwater monitoring wells, Rainier Mesa, Nevada National Security Site, Nevada. 


\section{Purpose and Scope}

This report documents a process for estimating net infiltration from micrometeorological data acquired at two sites on Rainier Mesa. The primary objectives of the study were to (1) correct and gap-fill existing precipitation and ET datasets, and (2) develop a method that uses the corrected datasets to estimate net infiltration. Net infiltration is defined in this study as water percolation below the root zone. Datasets were corrected for the 3-year period from July 1, 2002, to June 30, 2005. Soil samples were collected during May 2014 to determine physical and hydraulic properties and depth to bedrock. Net infiltration was simulated monthly with a water-balance model. All pertinent data and models are published in Smith and others (2017).

\section{Description of Measurement Sites}

The USGS operated two ET stations from January 1, 2002, to August 24, 2005 (fig. 1). The sites were located in homogeneous vegetation covers representative of the Rainier Mesa recharge area (DeMeo and others, 2006). The first site, referred to in this report as the "pinyon-juniper site," was in mixed pinyon pine (Pinus edulis) and juniper (Juniperus sp.) woodlands (DeMeo and others, 2006; fig. 2A). The second site, referred to in this report as the "scrub-brush site," was in high-desert scrub brush dominated by rabbitbrush (Chrysothamnus sp.) (fig. 2B). The pinyonjuniper and scrub-brush sites were at similar altitudes and separated by about 1.5 kilometers $(\mathrm{km})$ (table 1). Both sites were atop a thin layer ( $<40$ centimeters $[\mathrm{cm}]$ ) of loam to clay loam soil underlain by fractured welded-tuff bedrock. Continuous measurements at each site included the micrometeorological and energy-balance components necessary to calculate ET. Twentyminute-averaged measurements included latentand sensible-heat fluxes (sampled at 10 hertz), and net radiation, soil-heat flux, air temperature, wind speed, wind direction, and volumetric soil-water content (sampled at 10-second intervals).
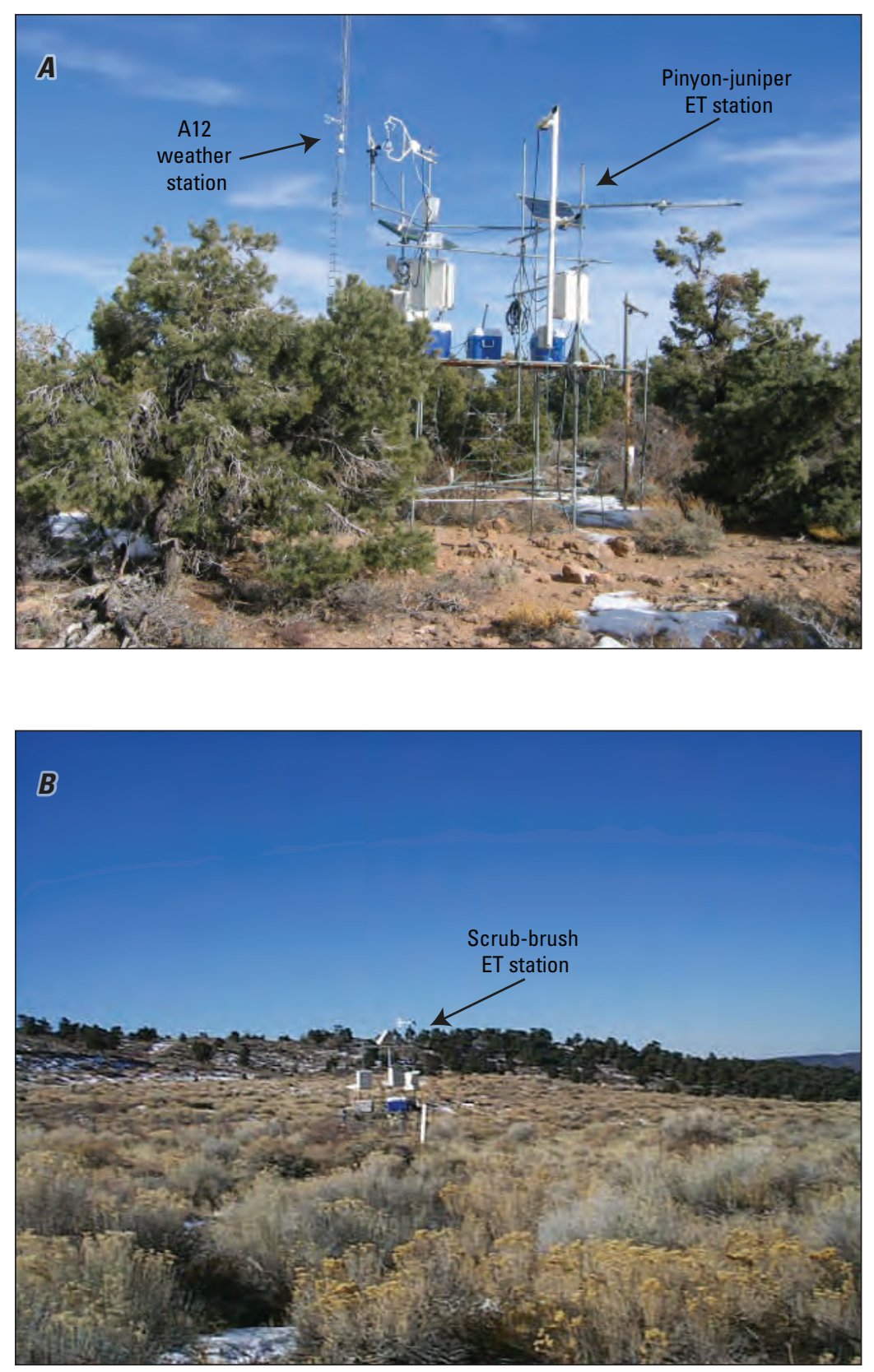

Figure 2. Evapotranspiration (ET) sites $(A) \mathrm{A} 12$ weather and pinyon-juniper ET stations, and $(B)$ scrub-brush ET station, Rainier Mesa, Nevada National Security Site, Nevada. Photograph by project staff, U.S. Geological Survey. 
Table 1. Location and general description of measurement sites, Rainier Mesa, Nevada National Security Site, Nevada, 2002-05.

[Latitudes and longitudes are referenced to North American Datum of 1983. Altitude: Distance above North American Vertical Datum 1988. Abbreviations: NOAA, National Oceanic and Atmospheric Administration; USGS, U.S. Geological Survey; m, meter; N/A, not applicable]

\begin{tabular}{lcccccccc}
\hline $\begin{array}{c}\text { Measurement } \\
\text { site }\end{array}$ & $\begin{array}{c}\text { USGS or } \\
\text { NOAA site } \\
\text { identifier }\end{array}$ & $\begin{array}{c}\text { Measurement } \\
\text { type }\end{array}$ & $\begin{array}{c}\text { Latitude } \\
\text { (decimal } \\
\text { degrees) }\end{array}$ & $\begin{array}{c}\text { Longitude } \\
\text { (decimal } \\
\text { degrees) }\end{array}$ & $\begin{array}{c}\text { Altitude } \\
\text { (m) }\end{array}$ & $\begin{array}{c}\text { Vegetation } \\
\text { type }\end{array}$ & $\begin{array}{c}\text { Vegetation } \\
\text { cover } \\
\text { (percent) }\end{array}$ & $\begin{array}{c}\text { Average } \\
\text { vegetation } \\
\text { height } \\
\text { (m) }\end{array}$ \\
\hline Pinyon-juniper $^{1}$ & 371128116125901 & Evapotranspiration & 37.191 & -116.216 & 2,283 & $\begin{array}{c}\text { Pinyon-juniper } \\
\text { woodland }\end{array}$ & $20-30$ & 3 \\
Scrub-brush $^{1}$ & 371048116122501 Evapotranspiration & 37.180 & -116.207 & 2,290 & $\begin{array}{c}\text { High-desert } \\
\text { scrub brush }\end{array}$ & $10-20$ & 0.25 \\
Rainier Mesa $^{2}$ & A12 & Precipitation & 37.190 & -116.220 & 2,283 & N/A & N/A & N/A \\
Desert Rock Airport $^{2}$ & DRA & Net radiation & 36.621 & -116.026 & 990 & N/A & N/A & N/A \\
\hline
\end{tabular}

${ }^{1}$ DeMeo and others (2006).

${ }^{2}$ Soule (2006).

Precipitation (rain and snow) on Rainier Mesa is measured at weather station A12, a National Oceanic and Atmospheric Administration (NOAA) Special Operations Research Division weather station (Soule, 2006). Uncorrected daily precipitation data were acquired from the $\mathrm{A} 12$ weather station and used for water-budget analyses (National Oceanic and Atmospheric Administration, 2015). The A12 weather station was collocated with the pinyon-juniper ET station during the study period (figs. 1 and $2 A$, table 1). Precipitation at A12 was collected by an unshielded $20-\mathrm{cm}$ weighing precipitation gage with an orifice height 1 meter $(\mathrm{m})$ above land surface. Precipitation data were not collected at the scrub-brush ET site.

\section{Hydrogeology of Rainier Mesa}

Rainier Mesa is the highest point (about 2,340 m) within the NNSS and is a groundwater recharge area (Fenelon and others, 2008). This volcanic upland is preserved, in part, by a dense cap of welded tuff identified as the Timber Mountain welded-tuff formation (Fenelon and others, 2008). The Tertiary-age heavily fractured welded-tuff caprock extends from land surface to $80-170 \mathrm{~m}$ below land surface (bls) and overlies a thick sequence ( $>900 \mathrm{~m}$ ) of bedded tuffs (Thordarson, 1965; Fenelon and others, 2010). Precipitation periodically percolates beyond the influence of the dynamic near-surface ET zone and recharges the water table about $450 \mathrm{~m}$ bls (Fenelon and others, 2010).

Preferential flow through large structural deformations and cooling fractures in the volcanic tuffs is an important recharge process on Rainier Mesa. Contrarily, flow is extremely limited through the welded-tuff matrix because the saturated hydraulic conductivity is less than $5 \times 10^{-9} \mathrm{~m} / \mathrm{s}$ (Thordarson, 1965; Ebel and Nimmo, 2009). Various investigators used tunnels mined into the mesa to study the recharge process. Underground nuclear tests were done near or below the water table in 11 tunnels ranging from 0.06- to 24-km long (Ebel and Nimmo, 2009). Groundwater discharged to some of the tunnels through fractures and faults exposed during mining (Clebsch, 1960; Thordarson, 1965). Because discharge decreased with time, it was concluded that the fractures were disconnected. This conclusion is supported by Thordarson (1965), who noted that only 2 percent of roughly 5,000 fractures in $19 \mathrm{~km}$ of exposed tunnel yielded water.

Findings by some investigators suggest a fast component of flow, at least in a limited number of fractures and faults. For example, Clebsch (1961) measured increased tritium concentrations in tunnel discharge and concluded that the water was between 0.8 and 6 years old. Russell and others (1987) noted hydrograph responses in tunnel discharge following winter storms, suggesting a relatively fast response in the tunnel to recharge. Jacobson and others (1986) studied the chemistry of tunnel seeps and noted increased cation-tosilica ratios 1.5-3 months after a recharge event and increased tunnel discharge rates from 3-6 months after a recharge event. Additionally, bomb-pulse (cosmogenic isotope ${ }^{36} \mathrm{Cl}$ ) was detected in samples of water in a tunnel at depths of about $400 \mathrm{~m}$ below land surface (Norris and others, 1990). The ${ }^{36} \mathrm{Cl}$ was attributed to preferential flow of young recharge water along a nearby fault that intersected the tunnel.

Near-surface hydrologic processes of Rainier Mesa are conceptualized in figure 3. Continuous fractures to the water table provide a permeable pathway for water to percolate below the root zone. The soil zone beneath both ET sites is less than $0.4 \mathrm{~m}$; therefore, the storage of infiltrated precipitation in the soil is limited. Water storage likely is supplemented by a system of discontinuous fractures in the shallow bedrock. This discontinuous-fracture system comprises a shallow reservoir where precipitation stored during above-average years sustains vegetation during below-average years. The depth of vegetative roots extending into the fractured bedrock is identified as the root zone. 


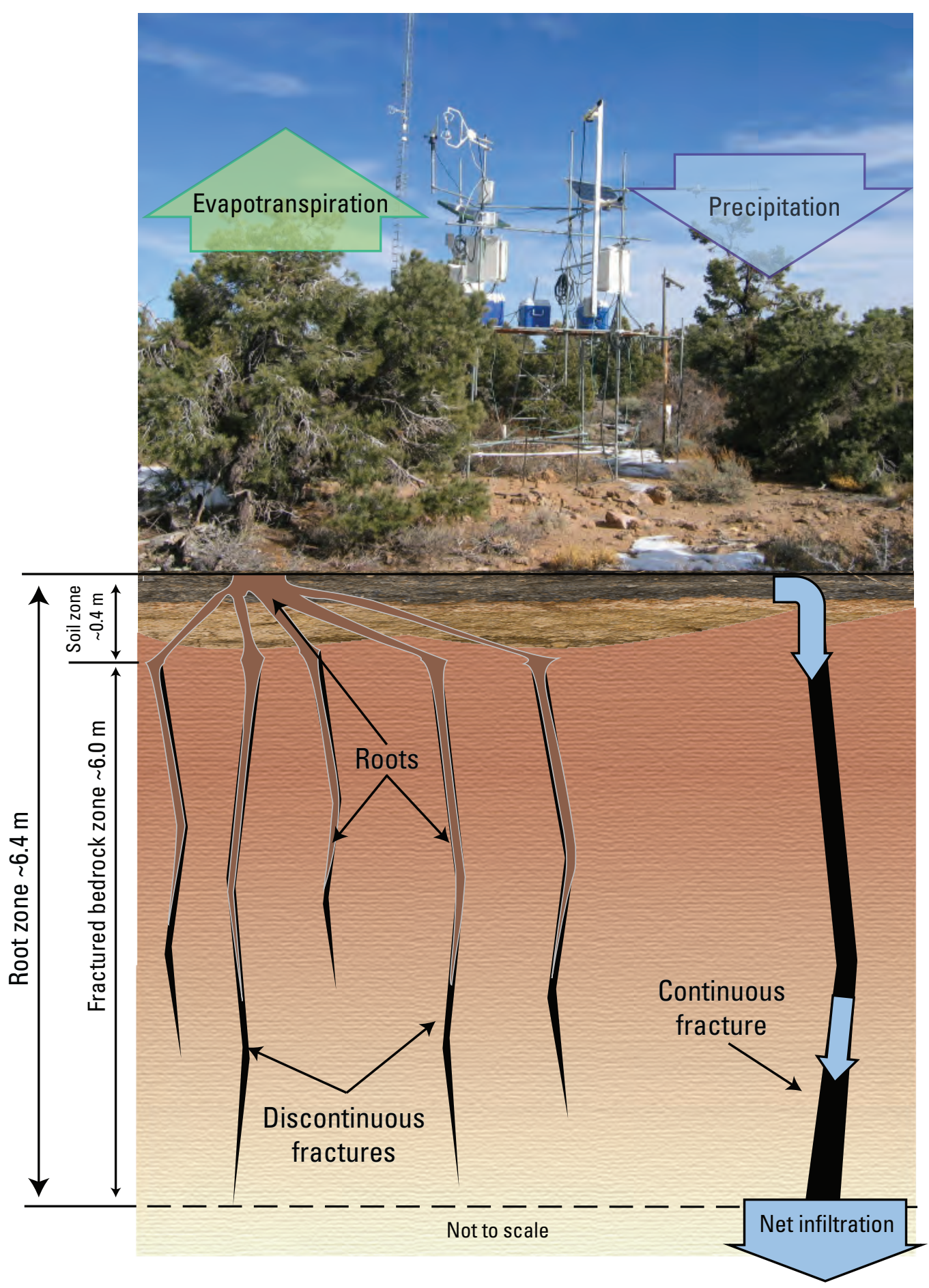

Figure 3. Photograph and conceptual diagram showing near-surface hydrologic processes, Rainier Mesa, Nevada National Security Site, Nevada. 
The maximum reported root depth of pinyon and juniper pine is $6.4 \mathrm{~m}$ in tuff bedrock formations (Foxx and Tierney, 1985). In this report, the deep percolation of water beneath the root zone is defined as net infiltration (Hevesi and others, 2003). The mechanisms controlling the rate of percolation below the root zone through the thick (300-500 m) unsaturated zone to recharge the water table are poorly understood; however, rising water levels in wells near Rainier Mesa following above-average precipitation years suggest that some recharge occurs rapidly through fracture flow.

Water levels in monitoring wells U12s, ER-12-1, and ER-19-1-3, drilled into granite, carbonate rock, and volcanic tuff, respectively, rose rapidly during late 2005 through 2006 (figs. 1 and 4). These rises are interpreted as a response to episodic pulses of recharge resulting from substantially above-average precipitation during the 2004-05 winter (Soule, 2006; Mirus and Nimmo, 2013). These rapid rises are consistent with preferential flow paths that allow recharge to reach the water table quickly (Thordarson, 1965; Ebel and Nimmo, 2009). Previous estimates of recharge to the water table on Rainier Mesa range from 5 (Belcher and others, 2004 ) to 50 millimeters per year (mm/yr) (Russell and Minor, 2002). Site-specific recharge rates, using a source-responsive model of water-level fluctuations in well ER-12-1, averaged $24 \mathrm{~mm} / \mathrm{yr}$ between 1993 and 2012 (Mirus and Nimmo, 2013). Average rates from four distributed recharge models ranged between 10 and $20 \mathrm{~mm} / \mathrm{yr}$ (Stoller-Navarro Joint Venture, 2008).

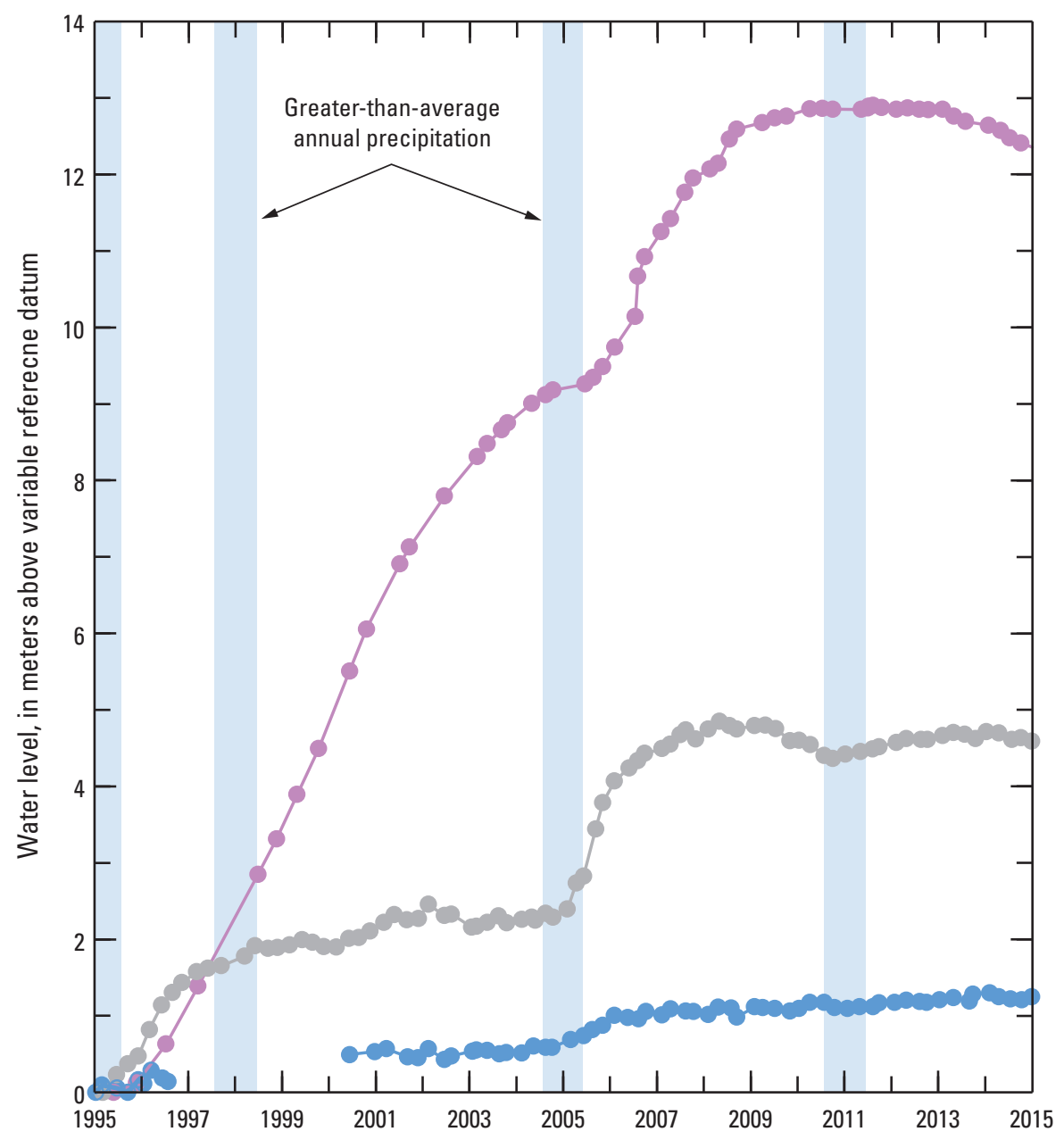

\section{EXPLANATION}

Monitoring wells<smiles>CO[135I]</smiles>

- ER-12-1

- ER-19-1-3

Figure 4. Hydrographs for selected monitoring wells, Rainier Mesa, Nevada National Security Site, Nevada, 1995-2015. 


\section{Water-Budget Methods}

Net infiltration was estimated based on a water balance between precipitation and ET. Existing precipitation and ET datasets required a number of gap-filling procedures and corrections to develop continuous datasets and to remove measurement biases. Precipitation data acquired from the A12 weather station were corrected for wind-induced gage-catch deficiencies. Micrometeorological data acquired from DeMeo and others (2006) were filtered to remove data spikes, corrected for frequency-response and energy-balance deficiencies, and gap-filled. Annual analysis periods (July 1-June 30 ) were selected to minimize the influence of antecedent soil-zone water storage on the water balance. Net infiltration and changes in root-zone water storage were estimated monthly using a water-balance model. All data were summarized annually.

\section{Precipitation Data Collection Methods}

All precipitation gages are subject to gage-catch deficiencies that result in an underestimation (negative bias) of true precipitation (Larson and Peck, 1974). The primary cause of gage-catch error is wind. A precipitation gage obstructs the wind stream, which creates turbulence around the orifice of the gage. This turbulence deflects precipitation that otherwise would have fallen into the orifice. The error increases as wind speeds increase, and wind speeds decrease following a logarithmic wind profile with decreasing height above the land surface or vegetation canopy (Campbell and Norman, 1998). To correct for this negative bias, wind speed at gageorifice height must be known or estimated. Accordingly, the daily average wind speed measured by the anemometer at A12 (10-m-high) was adjusted downward to the gage-orifice height (1 m) using the following equation (Yang and others, 1996):

$$
U(h)=\frac{\left[\ln \left(\frac{h}{z_{0}}\right)\right]}{\left[\ln \left(\frac{H}{z_{0}}\right)\right]} U(H)
$$

where

$U(h)$ is the estimated daily wind speed at the gage orifice, in meters per second,

$U(H) \quad$ is the measured daily wind speed by the anemometer, in meters per second,

$h \quad$ is the height of the gage orifice above land surface, in meters,

$H \quad$ is the height of the anemometer above land surface, in meters,

ln natural logarithm, and

$z_{0} \quad$ is the roughness parameter, in meters, estimated as $0.32 \mathrm{~m}$ (Hansen, 1993).
Daily average wind speeds $(U[H])$ were missing for 66 days when precipitation was measured at A12. Gaps in the $U(H)$ dataset were filled using height-corrected wind-speed data from the pinyon-juniper ET site if available (measured at 4-m height), or from the scrub-brush ET site (measured at 3-m height) when data from the pinyon-juniper ET site were not available.

Daily gage-catch ratios were computed from the gapfilled $U(h)$ dataset based on precipitation type. Precipitation measurement error is greater for solid (snow) than for liquid precipitation (rain) (Larsen and Peck, 1974; Groisman and others, 1991; Yang and others, 1996). Corrections for precipitation type (liquid, mixed, and solid) are identified by air temperature associated with transitions in precipitation type. Mixed and solid precipitation corrections are defined by temperatures ranging from 3 to $-2{ }^{\circ} \mathrm{C}$ and less than $-2{ }^{\circ} \mathrm{C}$, respectively (Yang and others, 1996). Gage-catch ratios $(R)$ were computed using the following equations (Yang and others, 1996):

$$
\begin{gathered}
R_{\text {solid }}=\exp \left(4.606-0.157 * U(h)^{1.28}\right) \\
R_{\text {mixed }}=100.77-8.34 * U(h) \\
R_{\text {liquid }}=\exp \left(4.605-0.062 * U(h)^{0.58}\right)
\end{gathered}
$$

where

$R \quad$ is the percentage of precipitation measured for solid, mixed, and liquid precipitation.

The following equation uses $R$ to correct gage-catch deficiencies:

$$
P=\frac{P_{m}}{R} * 100
$$

where

$$
\begin{array}{cl}
P & \text { is corrected precipitation, in millimeters, and } \\
P_{\mathrm{m}} & \text { is measured precipitation, in millimeters. }
\end{array}
$$

The corrected A12 precipitation dataset was used for water-balance calculations at both the pinyon-juniper and scrub-brush ET sites. The uncertainty of $P$ at the co-located pinyon-juniper ET site is estimated to be \pm 5 percent. An additional \pm 5 percent uncertainty is applied to the scrubbrush ET site to account for the distance between these sites $(1.5 \mathrm{~km})$; accordingly, a total $P$ uncertainty at the scrub-brush ET site of about \pm 7 percent was estimated by propagating these uncertainties "in quadrature" (the square root of the sum of squared measurement and distance uncertainties). $P$ and $P_{m}$ data are given in Smith and others (2017). 


\section{Evapotranspiration Data Collection Methods}

Evapotranspiration is the process that transfers water from the land surface to the atmosphere and occurs as evaporation (or sublimation when below freezing) from open water, soil, and plant canopies, and as transpiration from plants. Radiative energy originating from the sun is a large component of net radiation, and net radiation is the primary driver of ET processes. Net radiation $\left(R_{n}\right)$ is the difference between incoming and outgoing long-wave and shortwave radiation. Net radiation at the Earth's surface is partitioned into energy that is transferred by heat conducted downward into the subsurface $(G)$, by heat conducting or convecting upward into the atmosphere $(H)$, or by conversion of water from the solid or liquid phase to the vapor phase $(L E)$

(Brutsaert, 1982). This partitioning process, which is based on the conservation of energy principle, can be expressed as:

$$
R_{n}-G=L E+H
$$

where

$$
\begin{aligned}
R_{n} & \text { is net radiation, } \\
G & \text { is soil-heat flux, } \\
L E & \text { is latent-heat flux, and } \\
H & \text { is sensible-heat flux. }
\end{aligned}
$$

All terms are in watts per square meter $\left(\mathrm{W} / \mathrm{m}^{2}\right)$, and each term is positive during typical daytime conditions. $R_{n}$ is positive when incoming long-wave and shortwave radiation exceeds outgoing long-wave and shortwave radiation, $G$ is positive when heat moves from the surface into the subsurface, and $L E$ and $H$ are positive when moving upward from the surface to the atmosphere. The left side of equation 6 represents the available energy and the right side the turbulent flux. Energy used for photosynthesis and energy stored as heat in short and sparse canopies are considered negligible for this study and are not accounted for in the energy-balance equation (Brutsaert, 1982; Wilson and others, 2002). A greater proportion of available energy is partitioned into $H$ in arid environments where water supplies are limited; however, following precipitation events, a greater proportion of available energy is partitioned into $L E$ due to the amount of energy consumed in the ET process.

DeMeo and others (2006) used eddy covariance to measure ET at the pinyon-juniper and scrub-brush sites. Eddies are turbulent airflows caused by wind, surface roughness, and convective heat flow in the atmospheric surface layer (Swinbank, 1951; Brutsaert, 1982; Kaimal and Finnigan, 1994). Eddies transfer energy and mass between the land surface and the atmosphere through a process referred to as turbulent energy exchange. Evapotranspiration (positive $L E$ ) occurs when water vapor in upward moving eddies is greater than in downward moving eddies. $L E$ is the product of the latent heat of vaporization of water $(\lambda)$ and water-vapor flux density. Water-vapor flux density is calculated as the covariance of instantaneous deviations from the time-averaged product of water-vapor density and vertical wind speed. $L E$ can be expressed mathematically as:

$$
L E=\lambda \overline{w^{\prime} \rho_{v}{ }^{\prime}}
$$

where

$$
\begin{aligned}
& \lambda \quad \text { is the latent heat of vaporization, in joules per } \\
& \text { gram, } \\
& w \quad \text { is vertical wind speed, in meters per second; } \\
& \text { and } \\
& \rho_{v} \quad \text { is water vapor density, in grams per cubic } \\
& \text { meter, where the overbar is the average and } \\
& \text { the prime is the deviation from the average } \\
& \text { over an averaging period. }
\end{aligned}
$$

Although slightly temperature-dependent, $\lambda$ is nearly a constant; therefore, the period of record mean air temperature was used to calculate $\lambda$. The ET rate was computed by dividing $L E$ by $\lambda$ and the density of water as described by Stannard and others (2013, p. 7).

$H$ is the movement of heat energy that results from a temperature gradient between the Earth's surface and the atmosphere. $H$ is computed from temperature and vertical wind speed as:

$$
H=\rho C_{p} \overline{w^{\prime} T_{a}^{\prime}}
$$

where

$$
\begin{aligned}
& \rho \quad \text { is air density, in kilograms per cubic meters, } \\
& C_{p} \quad \text { is specific heat of air, in joules per kilogram } \\
& \text { per degree Celsius, and } \\
& T_{a} \quad \text { is air temperature, in degrees Celsius, where } \\
& \text { the overbar is the average and the prime } \\
& \text { is the deviation from the average over an } \\
& \text { averaging period. }
\end{aligned}
$$

The ET sites established by DeMeo and others (2006) were equipped with sensors necessary to independently measure each of the energy-balance components in equation 6 at 20-minute intervals. $L E$ and $H$ were computed from rapid fluctuations in water-vapor density, wind-speed components, and air temperature measured by fast-response sensors. A krypton hygrometer was used to sample water-vapor density fluctuations, and a three-dimensional sonic anemometer sampled wind vector and air temperature fluctuations at 0.1 -second intervals. $R_{n}$ was measured with a net radiometer. $G$ was measured at each site using multiple soil-heat flux plates. Volumetric water content was measured by three water content reflectometers at each site representing an integrated average from 0 to $15 \mathrm{~cm}$ bls. Additional sensor descriptions and setup information is available in DeMeo and others (2006). 
Time-series data acquired from DeMeo and others (2006) required additional processing to develop the continuous datasets needed to estimate annual ET. Data filtering and gap-filling techniques documented by Law and others (2005), Moreo and Swancar (2013), and Garcia and others (2015) were adapted for processing of $L E, H$, and $R_{n}$ time-series data. Instrument malfunctions at the scrub-brush site resulted in no $L E$ data after July 2004. As a result, the period-of-record for water-budget analyses was July 1, 2002, to June 30 , 2005 , at the pinyon-juniper site and July 1, 2002, to June 30, 2004, at the scrub-brush ET site. Gaps in $G$ were not filled because (1) as much as 76 percent of annual data were missing and (2) the magnitude of $G$ is small over annual periods (Shuttleworth, 1993; Moreo and others, 2007; Garcia and others, 2015). The following sections describe the application of data filters, gap-filling techniques, and corrections.

\section{Filter and Gap-Filling Procedures}

Time-series data for $L E$ and $H$ were filtered to remove poor-quality or unrepresentative 20 -minute data resulting from sensor failure and limitations, site maintenance, and meteorological conditions (fig. 5). First, $L E$ and $H$ data spikes less than $-150 \mathrm{~W} / \mathrm{m}^{2}$ and greater than $700 \mathrm{~W} / \mathrm{m}^{2}$ were filtered (Law and others, 2005), then nighttime $\left(R_{n}<-5 \mathrm{~W} / \mathrm{m}^{2}\right) L E$ was filtered to limit values to lower and upper bounds of -50 and $50 \mathrm{~W} / \mathrm{m}^{2} . R_{n}$ data did not require filtering except for a few erroneous values caused by sensor maintenance during site visits. The annual percentage of missing or filtered flux data ranged from 3 to 44 percent at the pinyon-juniper and 3 to 22 percent at the scrub-brush ET sites (table 2).

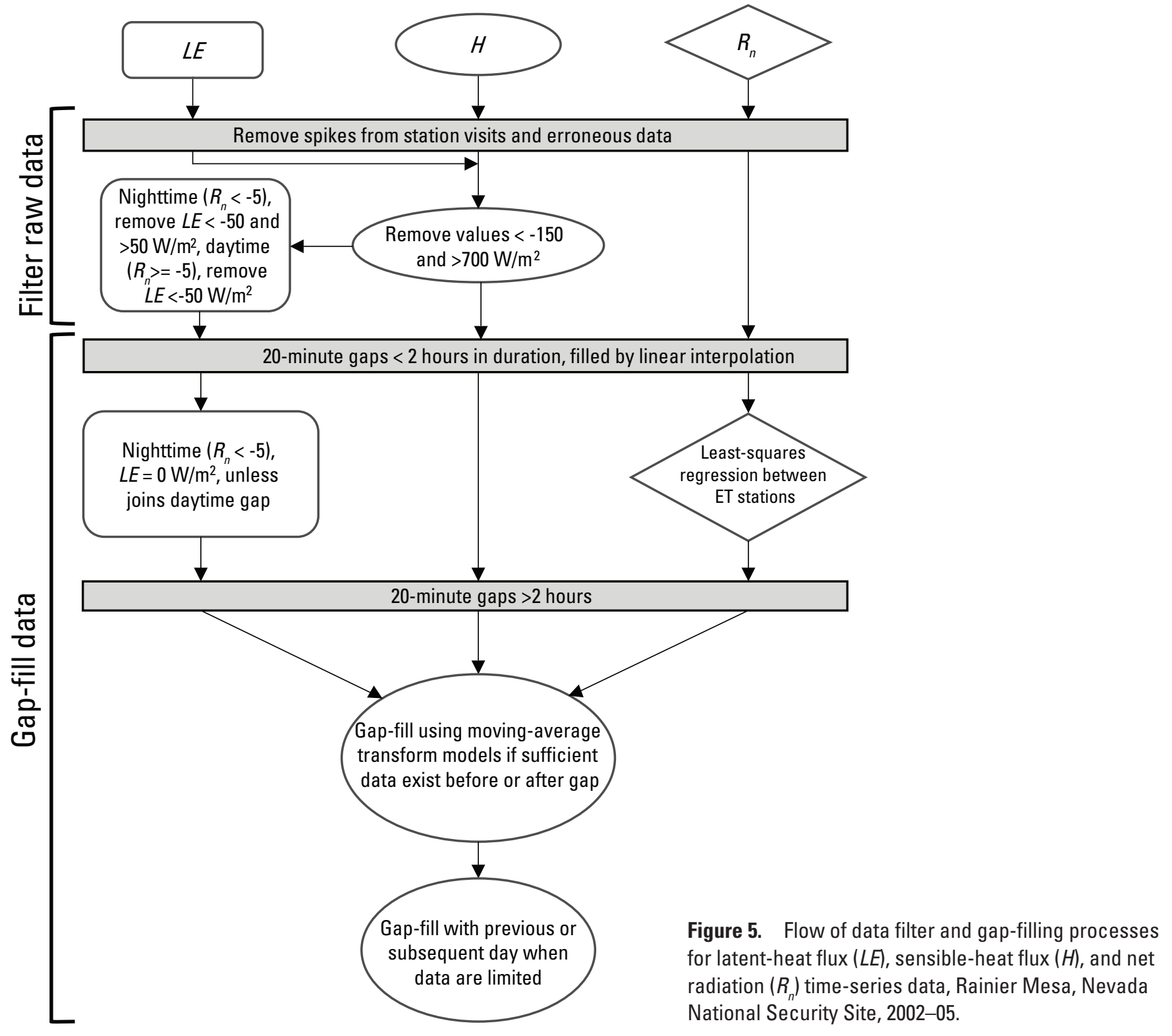


Table 2. Percentage of missing or filtered 20-minute net radiation, latent-heat flux, and sensible-heat flux data at the pinyon-juniper and scrub-brush evapotranspiration sites, Rainier Mesa, Nevada National Security Site, July 1, 2002-June 30, 2005.

[Missing or filtered data: $R_{n}$, Net radiation; $L E$, Latent-heat flux; $H$, Sensibleheat flux]

\begin{tabular}{lcrrr}
\hline \multirow{2}{*}{$\begin{array}{c}\text { Evapotranspiration } \\
\text { site }\end{array}$} & Annual period & \multicolumn{3}{c}{$\begin{array}{c}\text { Missing or filtered data } \\
\text { (percent) }\end{array}$} \\
\cline { 3 - 5 } & & $\boldsymbol{R}_{\boldsymbol{n}}$ & $\boldsymbol{L E}$ & $\boldsymbol{H}$ \\
\hline Pinyon-juniper & 07-01-02 to 06-30-03 & 44 & 38 & 38 \\
& $07-01-03$ to 06-30-04 & 3 & 7 & 9 \\
& 07-01-04 to 06-30-05 & 14 & 10 & 18 \\
\hline Scrub-brush & 07-01-02 to 06-30-03 & 18 & 19 & 22 \\
& 07-01-03 to 06-30-04 & 3 & 13 & 15 \\
\hline
\end{tabular}

Data processing to develop continuous gap-filled datasets was done using the Microsoft Excel ${ }^{\circledR}$ add-in SeriesSEE (Halford and others, 2012). The procedures used to gap-fill $L E, H$, and $R_{n}$ time-series datasets varied depending on the (1) length of the gap, (2) flux type, and (3) time of day that the gap occurred (fig. 5). Gaps of less than 2 hours in each dataset were filled by linear interpolation. Gaps of 2 hours or more in the $R_{n}$ datasets were filled by least-square regression of pinyon-juniper compared with scrub-brush site values $\left(\mathrm{r}^{2}=0.91\right)$. Gaps of 2 hours or more in $L E$ datasets at night were set equal to zero because minimal energy is available during nighttime to drive ET processes. The remaining gaps in $L E, H$, and $R_{n}$ datasets were simulated with moving average transforms in SeriesSEE (Halford and others, 2012; Garcia and others, 2015). Fluxes were simulated with model inputs of pertinent time-series data, such as $L E, H, R_{n}$, air temperature, and precipitation. The model inputs represented predictor variables with multiple signals and frequencies to simulate environmental fluctuations prior and (or) subsequent to data gaps. Model inputs were transformed into functions, herein identified as model components, with a moving average transform. The model components represent the trends and conditions at time $(t)$ and are summed to the simulated flux (SF) by the following equation (Halford and others, 2012):

$$
S F(t)=C_{0}+\sum_{i=1}^{n} M C(t)_{i}
$$

where

$$
\begin{gathered}
C_{0} \quad \text { is a constant equal to the summation of all } \\
\text { y-intercepts from each component, in watts } \\
\text { per square meter, } \\
n \quad \text { is the number of components, } \\
M C_{i} \quad \text { is the ith model component, in watts per } \\
\text { square meter. }
\end{gathered}
$$

Moving-average transforms were applied to the model components at time $(t)$ by:

$$
M C(t)_{i}=a_{i} V_{i}\left(t+\phi_{i}\right)
$$

where

$$
\begin{aligned}
& a_{i} \quad \text { is the amplitude multiplier of the } i \text { th } \\
& \text { component in units of the simulated flux } \\
& \text { divided by units of the ith component, } \\
& \phi \quad \text { is the phase-shift of the ith component, and } \\
& V_{i}\left(t+\phi_{i}\right) \quad \text { is the value of the moving average of the } i \text { th } \\
& \text { component at time } t+\phi_{i} \text { in units of the ith } \\
& \text { component. }
\end{aligned}
$$

A large range of moving averages was selected as model components due to a broad range of averaging periods helping to minimize model error (Halford and others, 2012). SeriesSEE uses Parameter ESTimation (PEST; Doherty, 2010) to automatically calibrate the amplitude and phase-shift of the model components to minimize the error between the simulated and measured fluxes prior and (or) subsequent to data gaps. After error between the measured and simulated flux is minimized, the simulated flux is projected through the gap period(s) and model error is reported as the root-meansquare-error (Halford and others, 2012). Gaps were filled sequentially using moving average transformations as follows: (1) $R_{n}$, (2) $H$, and (3) $L E$. When $R_{n}$ data were not available either from the pinyon-juniper or scrub-brush sites, $R_{n}$ data from the NOAA Desert Rock Airport station were used (Soule, 2006; fig. 1 and table 1). Gaps in $H$ data were modeled using moving averages of gap-filled $R_{n}$ and $H$ fluxes. Gaps in $L E$ data were modeled using moving averages of $R_{n}, H$, and Priestly-Taylor modeled LE fluxes. The Priestley-Taylor equation is (Priestley and Taylor, 1972):

$$
L E=\alpha \frac{\Delta}{\Delta+\gamma}\left(R_{n}-G\right)
$$

where

$$
\begin{gathered}
L E \quad \text { latex heat flux, } \\
\alpha \quad \text { is an empirically determined dimensionless } \\
\text { coefficient that was allowed to vary during } \\
\text { the fitting process, } \\
\Delta \quad \text { is the slope of the saturation vapor pressure- } \\
\text { temperature curve (kilopascals per degrees } \\
\text { Celsius), and } \\
\gamma \quad \text { is the psychrometric constant, in kilopascal } \\
\text { per degree Celsius, pressure-corrected for } \\
\text { site altitude. }
\end{gathered}
$$

Air temperature ( $T_{a}$ in degrees Celsius) was used to compute the second term on the right side of equation 12 using a polynomial regression equation fit to data from Shuttleworth (1993, table 4.1.1) with the psychrometric constant:

$$
\frac{\Delta}{\Delta+\gamma}=-0.00015 T_{a}^{2}+0.017 T_{a}+0.430
$$


Additionally, gaps in $L E$ fluxes coinciding with precipitation were modeled with the gamma function to improve goodnessof-fit (Halford and others, 2012). The gamma function was used to adjust the attenuation, intensity, and length of $L E$ fluxes after precipitation events (Garcia and others, 2015). An inventory of gap-filling procedures applied to $L E, H$, and $R_{n}$ data and goodness-of-fit model results are given in Smith and others (2017).

\section{Frequency-Response and Energy-Balance Corrections}

Several corrections commonly are applied to raw eddy-covariance fluxes to compensate for limitations both in eddy-covariance theory and equipment design. The following corrections were applied by DeMeo and others (2006): (1) the variation in the density of rising and falling air was corrected following Webb and others (1980), (2) the attenuation of the krypton hygrometer signal caused by oxygen sensitivity was corrected as suggested by Tanner and Greene (1989), and (3) air density and sound-path deflection of sonicderived temperatures was corrected using Schotanus and others (1983). The following corrections were not applied by DeMeo and others (2006): (1) two-dimensional coordinate rotation of raw covariances to correct small misalignments of the three-dimensional sonic anemometer that force the average vertical and crosswind velocities to zero (Kaimal and Finnigan, 1994); (2) frequency-response corrections owing to averaging time, sensor geometry, and sensor separation (Moore, 1986); and (3) corrections for energy imbalances. For this study, coordinate rotation corrections could not be applied because the raw covariance data were not available. Frequency response corrections were applied following the procedures outlined by Moore (1986). Although frequency response corrections typically are applied before the density and oxygen corrections and data reduction to 20- or 30-minute averages, only 20 -minute density and oxygen corrected data were available; therefore, frequency response corrections were applied to corrected and averaged data with an average increase of $H$ and $L E$ fluxes by approximately 1 and 2 percent, respectively.

Corrections for energy imbalances were applied to the ET dataset. The accuracy of eddy covariance turbulent-flux $(L E+H)$ measurements commonly is assessed based on the energy-balance closure method. This method is based on the conservation of energy principle, where the degree to which energy-balance closure is achieved is quantified by the energybalance ratio (EBR) (Wilson and others, 2002):

$$
E B R=\frac{L E+H}{R_{n}-G} .
$$

Ideally, if all energy fluxes are measured accurately (within limits of measurement accuracy), then the $E B R$ will equal unity. In reality, eddy covariance turbulent flux (eq. 13 numerator) is consistently less than the available energy (eq. 13 denominator). Typical $E B R$ values range from 0.6 to 1.0 , but most frequently range from 0.7 to 0.8 (Twine and others, 2000; Wilson and others, 2002; Foken, 2008). Although various theories have been advanced to explain the EBR discrepancy, currently (2016) there is no consensus about which of the following theories is correct: (1) turbulent flux is underestimated, or (2) available energy is overestimated (Wilson and others, 2002). Foken (2008) and Foken and others (2012) noted that turbulent fluxes often are underestimated because eddy-covariance measurements miss large-scale turbulent exchange fluxes, whereas Leuning and others (2012) note that available energy can be overestimated because of the inability to accurately estimate energy stored in soils, air, and biomass (Leuning and others, 2012).

Annual EBRs were computed for the pinyon-juniper and scrub-brush ET sites (table 3). Energy-balance analyses included only daily periods for which 72 good (non-gap-filled) 20-minute measurements were available.

Table 3. Annual energy-balance fluxes and ratios at the pinyon-juniper and scrub-brush evapotranspiration sites, Rainier Mesa, Nevada National Security Site, Nevada, July 1, 2002-June 30, 2005.

[All values in watts per square meter unless otherwise noted. $\boldsymbol{R}_{n}$ : Net radiation. $\boldsymbol{G}$ : Soil-heat flux (estimated as 0). $\boldsymbol{L} \boldsymbol{E}$ : Latent-heat flux. $\boldsymbol{H}$ : Sensible-heat flux. Available energy: Computed as $R_{n}$ minus $G$. Turbulent flux: Computed as $L E$ plus $H$. EBR: Energy-balance ratio, computed as turbulent flux divided by available energy]

\begin{tabular}{lcccccccc}
\hline $\begin{array}{c}\text { Evapotranspiration } \\
\text { site }\end{array}$ & Annual period & $\boldsymbol{R}_{\boldsymbol{n}}$ & $\mathbf{G}$ & $\boldsymbol{L E}$ & $\boldsymbol{H}$ & $\begin{array}{c}\text { Available } \\
\text { energy }\end{array}$ & $\begin{array}{c}\text { Turbulent } \\
\text { flux }\end{array}$ & $\begin{array}{c}\boldsymbol{E B R} \\
\text { (unitless) }\end{array}$ \\
\hline Pinyon-juniper & 07-01-02 to 06-30-03 & 111 & 0 & 18 & 66 & 111 & 85 & 0.77 \\
& $07-01-03$ to 06-30-04 & 115 & 0 & 29 & 70 & 115 & 99 \\
& 07-01-04 to 06-30-05 & 115 & 0 & 31 & 65 & 115 & 96 & 0.86 \\
& Mean 07-01-02 to 06-30-05 & $\mathbf{1 1 4}$ & $\mathbf{0}$ & $\mathbf{2 6}$ & $\mathbf{6 7}$ & $\mathbf{1 1 4}$ & $\mathbf{9 3}$ & $\mathbf{0 . 8 2}$ \\
\hline Scrub-brush & 07-01-02 to 06-30-03 & 88 & 0 & 19 & 61 & 88 & 80 & 0.91 \\
& 07-01-03 to 06-30-04 & 92 & 0 & 28 & 49 & 92 & 77 & 0.83 \\
& Mean 07-01-02 to 06-30-04 & $\mathbf{9 0}$ & $\mathbf{0}$ & $\mathbf{2 3}$ & $\mathbf{5 5}$ & $\mathbf{9 0}$ & $\mathbf{7 8}$ & $\mathbf{0 . 8 7}$ \\
\hline
\end{tabular}


The mean period-of-record $E B R$ for the pinyon-juniper and scrub-brush ET sites were 0.82 and 0.87 , respectively, indicating that 82 and 87 percent of measured available energy was accounted for by measured turbulent fluxes. Energy imbalances were corrected and uncertainties estimated as described in Moreo and Swancar (2013) and Garcia and others (2015). Briefly, energy imbalanced $L E$ and $H$ were assumed to represent probable minimums, and probable maximums were computed by adjusting $L E$ and $H$ upward to achieve energy-balance closure while maintaining consistency with the Bowen ratio. The Bowen ratio represents the ratio of $H$ to $L E$. The best estimate of $L E$ and $H$ for this study was assumed to be the mean of probable minimum and maximum estimates and uncertainty was assumed to be the difference between the best estimate and the probable minimum or maximum. Annual uncertainties ranged from 7 to 13 percent at the pinyon-juniper and 5 to 9 percent at the scrub-brush ET sites. Continuous ET datasets computed from gap-filled and corrected 20-minute energy-balance data are given in Smith and others (2017).

\section{Root-Zone Properties}

Soil samples were collected to determine physical and hydraulic properties, which were used to compute the available water capacity $(A W C)$ and estimate maximum root-zone water storage $\left(S_{\max }\right)$. Replicate soil cores $(\mathrm{n}=3)$ were collected for three depth intervals at each site during April-May 2014 (table 4). Cores were collected between 0 and $38 \mathrm{~cm}$ bls at the pinyon-juniper and 0 and $33 \mathrm{~cm}$ bls at the scrub-brush sites. Maximum core depths correspond to the depth to bedrock at each site. Standard laboratory measurements of texture (hydrometer) and moisture retention characteristics (five-point tension analysis) were made (table 4). The $A W C$ is the amount of stored water available to plants and was computed using the following equation (Salter and Williams, 1965; U.S. Department of Agriculture, 2005):

$$
A W C=\left(\theta_{\text {sat }}-\theta_{15}\right) \times z
$$

where

$$
\begin{array}{cl}
A W C & \text { is available water capacity, in millimeters, } \\
\theta_{\text {sat }} & \begin{array}{c}
\text { is volumetric water content at saturation, in } \\
\text { cubic centimeter per cubic centimeter, }
\end{array} \\
\theta_{15} & \begin{array}{l}
\text { is volumetric water content at }-15 \text { bar matric } \\
\text { potential, in cubic centimeter per cubic }
\end{array} \\
& \begin{array}{c}
\text { centimeter, } \\
\text { is the length evaluated, in centimeters. }
\end{array}
\end{array}
$$

Table 4. Root-zone properties including available water capacity and maximum water storage estimated at the pinyon-juniper and scrub-brush evapotranspiration sites, Rainier Mesa, Nevada National Security Site, Nevada.

[Zones are shown in figure 3. AWC: available water capacity. z: length evaluated. A bbreviations: $\mathrm{cm}$, centimeter; bls, below land surface; $\mathrm{cm}^{3} / \mathrm{cm}^{3}, \mathrm{cubic}$ centimeters per cubic centimeter; fc, field capacity; mm, millimeter; $\theta$, volumetric water content; sat, saturation; $15,-15$ bar matric potential; $S_{\text {max }}$, maximum root-zone water storage]

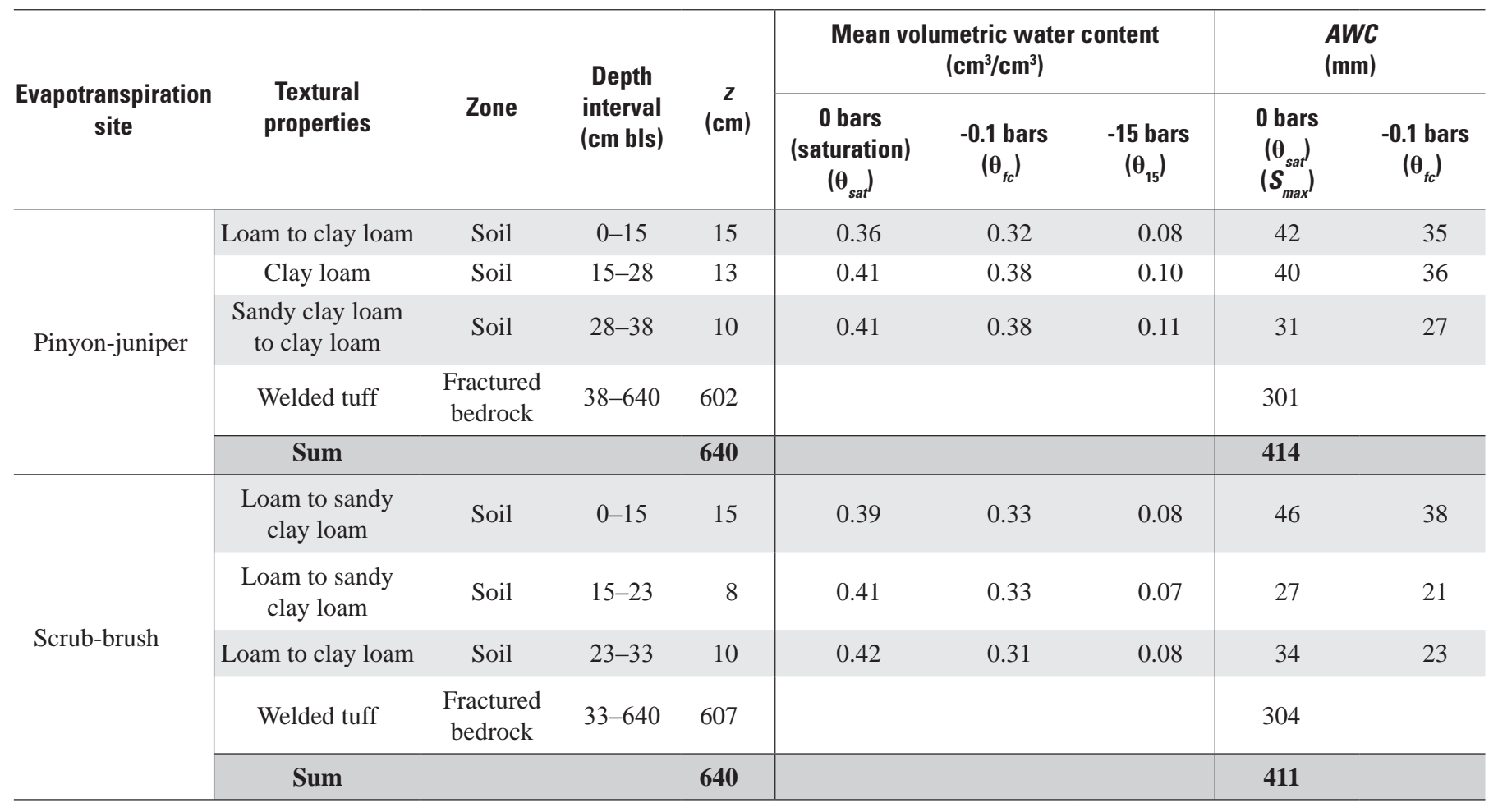


The volumetric water content at -15 bars matric potential $\left(\theta_{15}\right)$ represents the permanent wilting point of many species. The permanent wilting point is the water content at which plant roots cannot extract water because the water is held too tightly by the soil matrix. Although wilting points of the xerophytic species evaluated in this study likely occur below -15 bars, matric potential changes below this value likely will yield negligible water content changes; therefore, a permanent wilting point of -15 bars was considered sufficient to estimate $A W C$ (that is, $A W C=0 \mathrm{~mm}$ at -15 bars). The volumetric water content at -0.1 bars matric potential represents the field capacity. Field capacity is the volumetric water content following gravity drainage of recent precipitation. AWC is commonly computed using field capacity; however, the $A W C$ was computed from water contents at saturation rather than field capacity for the current study because the primary purpose of this calculation was to estimate the maximum root-zone water storage $\left(S_{\text {max }}\right)$ for water accounting purposes. Using the saturated water content to calculate $A W C$ for the water balance approach is consistent with a saturated condition in the soil and shallow bedrock being a threshold for the initiation of preferential flow through bedrock fractures that triggers net infiltration below the root zone. The AWC at field capacity and maximum water storage $\left(S_{\max }\right)$ are given in table 4.

Root zone $S_{\max }$ was estimated by summing $S_{\max }$ computed for the relatively thin $(<0.4 \mathrm{~m})$ soil zone, described in the previous paragraph, and relatively thick (about $6 \mathrm{~m}$ ) fractured-bedrock zone (fig. 3). Bedrock properties data were insufficient to determine $A W C$; therefore, two key assumptions were required to estimate bedrock-zone $S_{\max }$. First, the thickness of the root zone was estimated based on literature values of maximum root depths $(6.4 \mathrm{~m})$ for pinyon and juniper pines (Foxx and Tierney, 1985). Second, the bedrock porosity was estimated as 5 percent based the mean of a textbook range (0 to 10 percent) for fractured crystalline rock (Freeze and Cherry, 1979, p. 36). Accordingly, bedrock-zone $S_{\max }$ was computed by multiplying the bedrock-zone lengths by the porosity. The resulting root-zone $S_{\max }$ estimates for the pinion-juniper (414 $\mathrm{mm}$ ) and scrub-brush $(411 \mathrm{~mm})$ sites were similar.

\section{Water-Budget Equation}

A water budget simply states that the rate of change in water stored in a representative volume is balanced by the rate at which water flows in and out of the volume. Measured changes in the water balance over time can be used to assess the effects of climate variability on water resources (Healy and others, 2007). Site-scale hydrologic processes at the pinyon-juniper and scrub-brush sites were evaluated using the following equation:

$$
N I=P-E T-\Delta S
$$

where

$$
\begin{aligned}
N I & \text { is net infiltration, } \\
P & \text { is precipitation, } \\
E T & \text { is evapotranspiration, and } \\
\Delta S & \text { is the change in root-zone water storage. }
\end{aligned}
$$

All terms are in millimeters per year. Although surface runoff in ephemeral washes has occurred at the NNSS (French and others, 1996; Savard, 1998), no runoff was reported for the areas near the ET sites (DeMeo and others, 2006); therefore, runoff is assumed negligible and not accounted for in equation 15. $P$ and $E T$ were measured and estimated as described previously. $N I$ and $\Delta S$ were estimated based on the following one-dimensional water-balance model.

\section{Water-Balance Model}

In deep water-table settings, such as at Rainier Mesa, the use of a simple water-balance or "bucket" model has been a simple and effective way to represent soil moisture dynamics in the vegetative root zone and estimate effective infiltration (Rodriguez-Iturbe and others, 1999; Guswa and others, 2002, p. 2; Walker and others, 2002 p. 74; O'Reilly, 2004). The water-balance model used in the current study was modified from O'Reilly (2004). The model simulates $\triangle S$ with $P$ filling and $E T$ emptying the bucket. The size of the bucket is based on the total $A W C$ of the root-zone. If the bucket is filled beyond its maximum storage capacity $\left(S_{\max }\right)$, percolation below the root zone is assumed. Percolation below the root zone is defined in this study as net infiltration (NI). Net infiltration as an indicator of recharge is supported by rising water levels and increased tunnel discharge following above-average precipitation years (see section, "Hydrogeology of Rainier Mesa"). Model inputs are the continuous $P$ and $E T$ datasets described previously. $\Delta S$ was simulated by applying the following equation:

$$
\Delta S=P(t)-E T(t)
$$

where

$$
t \quad \text { is timescale. }
$$

At the monthly timescale:

$$
S^{i}=S^{i-1}+\left(P^{i}-E T^{i}\right)
$$

where

$$
\begin{aligned}
& S^{i} \quad \text { is root-zone storage at timestep } i \text {, in } \\
& \text { millimeters, } \\
& S^{i-1} \quad \text { is root-zone storage at previous timestep } i-1 \text {, } \\
& \text { in millimeters, } \\
& P^{i} \quad \text { is sum of corrected precipitation, in } \\
& \text { millimeters, } \\
& \text { ET is sum of corrected evapotranspiration, in } \\
& \text { millimeters, and } \\
& i^{-1} \quad \text { is timestep (monthly). }
\end{aligned}
$$


The model requires parameters of root-zone storage at the beginning of the simulation (study) period $\left(S_{b}\right)$ and $S_{\max }$. Net infiltration is conditional and is simulated when the root-zone storage $\left(S^{i}\right)$ exceeds the $S_{\max }$ (modified from O’Reilly, 2004):

$$
N I^{i}=\left\{\begin{array}{cl}
\frac{S^{i}-S_{\max }}{\Delta t} & \text { for } S^{i}>S_{\max } \\
0 & \text { for } S^{i} \leq \mathrm{S}_{\max }
\end{array}\right.
$$

where

$$
\begin{aligned}
& N I^{i} \quad \text { is net infiltration over time interval } i \text {, in } \\
& \text { millimeters. }
\end{aligned}
$$

\section{Model Calibration}

Root-zone water storage $(S)$ at the beginning of the study period $\left(S_{b}\right)$ was not known. However, an assumption was made that ET completely depleted root-zone water storage $(S=0)$ at the driest point in the study period. This assumption is not unreasonable considering that 1999-2004 was the longest dry (below-average precipitation) period on record, with 2003-04 being amongst the driest (see section, "Precipitation Estimates"). Applying the assumption to the pinyon-juniper site, $S_{b}$ was computed to be $178 \mathrm{~mm}$ by iteratively varying $S_{b}$ until the minimum monthly $S$ was $0 \mathrm{~mm}$ at some point during the study period (bucket is empty). The assumption results in an initial root zone water-storage depletion estimate of $236 \mathrm{~mm}\left(S_{\max }[414 \mathrm{~mm}]\right.$ minus $\left.S_{b}[178 \mathrm{~mm}]\right)$.

A sensitivity analysis was used to examine the sensitivity of $S_{b}$ on simulated NI. Net infiltration is considered sensitive to a parameter when a small change in the calibrated parameter value causes a large change in the simulated NI. The sensitivity of $S_{b}$ was examined by adjusting the initial root-zone storage by 5 and 10 percent (13 and $26 \mathrm{~mm}$ ). A 5 percent change corresponded to 12 percent $(13 \mathrm{~mm}$ ) change in simulated $N I$ over the study period. A 10 percent increase in $S_{b}$ resulted in a 25 percent $(26 \mathrm{~mm})$ in simulated $N I$. Thus, the analysis indicates that model simulation of $N I$ is sensitive to the initial $S_{b}$ conditions.

\section{Estimating Net Infiltration}

Net infiltration $(N I)$ was estimated based on a water balance between corrected precipitation $(P)$ and evapotranspiration (ET). Annual differences between $P$ and ET were partitioned between the change in root-zone water storage $(\Delta S)$ and $N I$ based on a monthly water-balance (bucket) model. The model simulates $\Delta S$ with $P$ filling the bucket and ET emptying the bucket. Net infiltration is assumed when the bucket is filled beyond its maximum storage capacity. Annual analysis periods (July 1-June 30) were selected to minimize the influence of antecedent soil-zone water storage on the water balance.

\section{Precipitation Estimates}

Annual corrected $P$ ranged from 184 to $708 \mathrm{~mm}$ during the July 1, 2002-June 30, 2005 study period (table 5; Smith and others, 2017). Gage-catch deficiency corrections increased $P_{m}$ totals by an average of 17.3 percent. The average gage-catch correction for the study period was applied to annual totals to compute an annual mean of $365 \mathrm{~mm}$ for the period July 1, 1959, to June 30, 2015 (fig. 6). Gaps in the A12 record $(1996,1997)$ were estimated from nearby gages, and the record was extended (2012-15) based on the replacement gage (M40; National Oceanic and Atmospheric Administration, 2015). Annual $P$ was (1) the fourth lowest on record $(n=55)$ during the first year (July 1, 2002-June 30, 2003), (2) slightly less than the annual mean during the second year (July 1, 2003-June 30, 2004), and (3) the second highest annual total on record during the third year of the study (July 1, 2004-June 30, 2005).

\section{Evapotranspiration Estimates}

Annual ET was 246, 413, and $433 \mathrm{~mm}$ at the pinyonjuniper ET site during the 3-year study, respectively, and 263 and $387 \mathrm{~mm}$ at the scrub-brush ET site during the first 2 years of the study, respectively (table 6; Smith and others, 2017). Annual ET averaged 18 percent greater and ranged from no change to 53 percent greater than annual ET reported by DeMeo and others (2006). Larger differences between DeMeo and others (2006) and this study occurred during annual periods with multiple data gaps exceeding 1 month in duration.

Evapotranspiration at both sites was within the uncertainty of one another during the first two annual periods of the study, indicating that annual ET is similar for these different vegetation types. Similarities in annual ET despite vegetative cover differences may be due to a larger proportion of bare-soil evaporation and sublimation compared to transpiration at these high-altitude sites. Moreo and others (2014) estimated that about 73 percent of annual ET could be attributed to bare-soil evaporation and sublimation, compared to only 27 percent transpiration in a ponderosa pine forest at an altitude of $2,630 \mathrm{~m}$ in southern Nevada.

Daily ET was greatest during spring and summer and least during autumn and winter (fig. 7A). 
Table 5. Annual precipitation measured at A12 weather station, precipitation corrected for gage-catch deficiencies, and precipitation uncertainty estimated for pinyon-juniper and scrub-brush evapotranspiration sites, Rainier Mesa, Nevada National Security Site, Nevada, July 1, 2002-June 30, 2005.

[All values in millimeters. Annual precipitation was summed from July 1 to June 30 each year. \pm , plus or minus]

\begin{tabular}{|c|c|c|c|c|}
\hline \multirow[t]{2}{*}{ Annual period } & \multirow{2}{*}{$\begin{array}{c}\text { Measured } \\
\text { precipitation } \\
\left(\boldsymbol{P}_{m}\right)\end{array}$} & \multirow{2}{*}{$\begin{array}{l}\text { Corrected } \\
\text { precipitation } \\
\qquad(P)\end{array}$} & \multicolumn{2}{|c|}{$\begin{array}{c}P \text { uncertainty } \\
( \pm)\end{array}$} \\
\hline & & & Pinion-juniper & Scrub-brush \\
\hline $07-01-02$ to $06-30-03$ & 154 & 182 & 9 & 13 \\
\hline $07-01-03$ to $06-30-04$ & 311 & 357 & 18 & 25 \\
\hline $07-01-04$ to $06-30-05$ & 599 & 708 & 35 & 50 \\
\hline
\end{tabular}

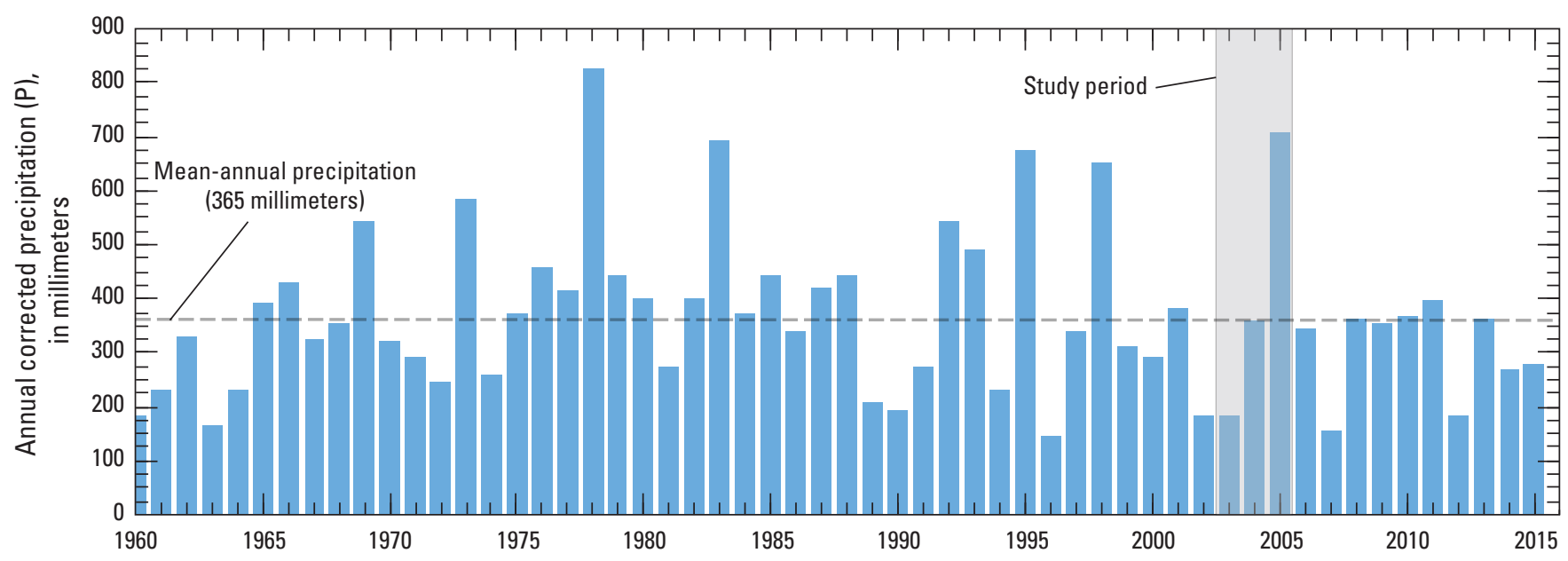

Figure 6. Annual precipitation corrected for gage-catch deficiencies, Rainier Mesa, Nevada National Security Site, Nevada, July 1, 1959-June 30, 2015. Annual precipitation was summed from July 1 to June 30 each year.

Table 6. Annual evapotranspiration and uncertainty estimated for the pinyon-juniper and scrub-brush evapotranspiration sites, Rainier Mesa, Nevada National Security Site, Nevada, July 1, 2002-June 30, 2005.

[All values in millimeters. Abbreviations: ET, evaportranspiration; \pm , plus or minus]

\begin{tabular}{lcccc}
\hline $\begin{array}{c}\text { Evapotranspiration } \\
\text { site }\end{array}$ & Annual period & $\begin{array}{c}\text { Reported ET } \\
\text { (DeMeo and } \\
\text { others, 2006) }\end{array}$ & $\begin{array}{c}\text { Corrected } E T \\
\text { (this study) }\end{array}$ & $\begin{array}{c}\text { ET } \\
\text { uncertainty } \\
(\mathbf{\pm})\end{array}$ \\
\hline Pinyon-juniper & 07-01-02 to 06-30-03 & 161 & 246 & 38 \\
& 07-01-03 to 06-30-04 & 375 & 413 & 33 \\
& 07-01-04 to 06-30-05 & 367 & 433 & 42 \\
\hline Scrub-brush & 07-01-02 to 06-30-03 & 263 & 263 & 13 \\
& 07-01-03 to 06-30-04 & 349 & 387 & 39 \\
\hline
\end{tabular}




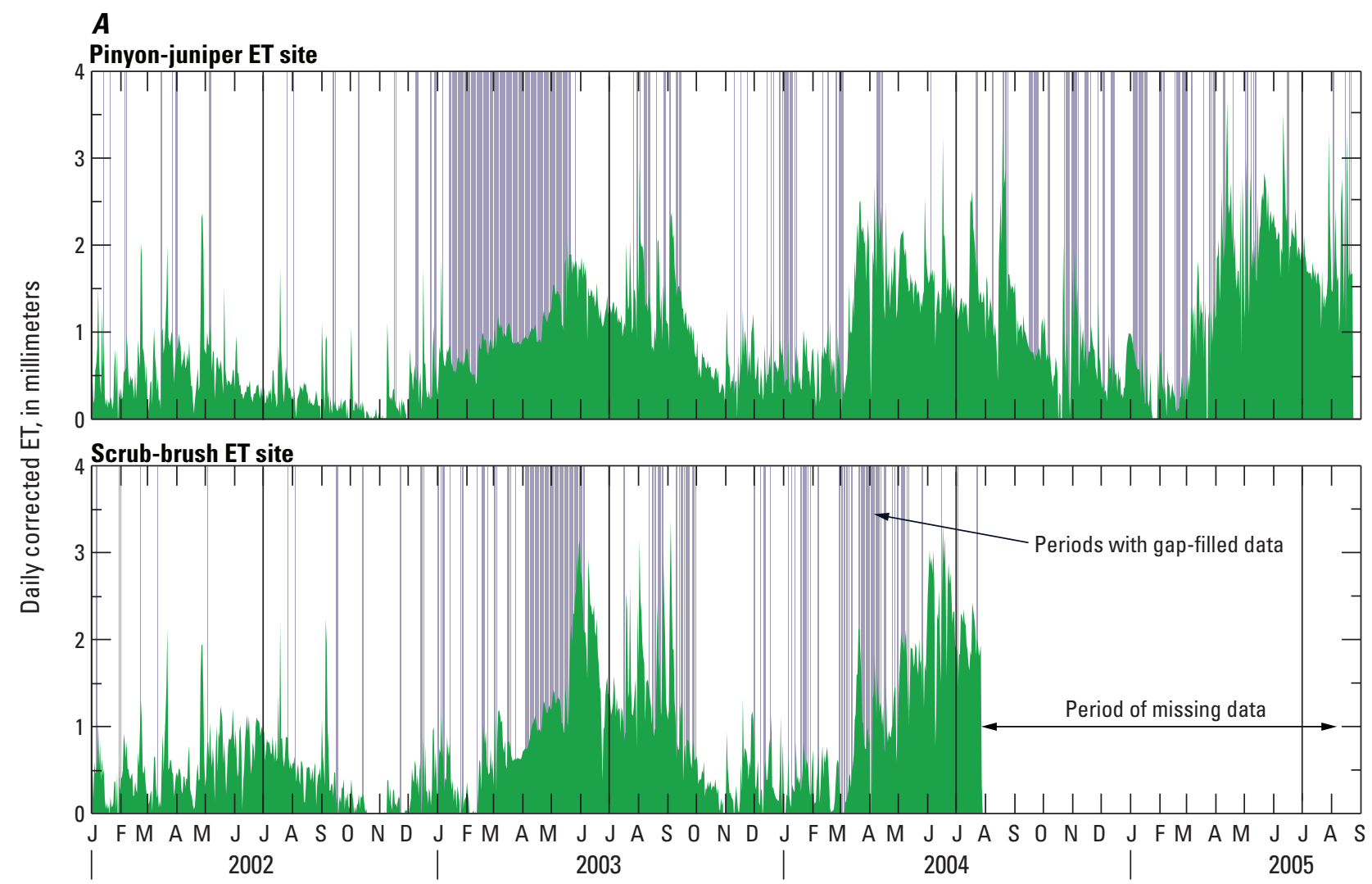

$\boldsymbol{B}$

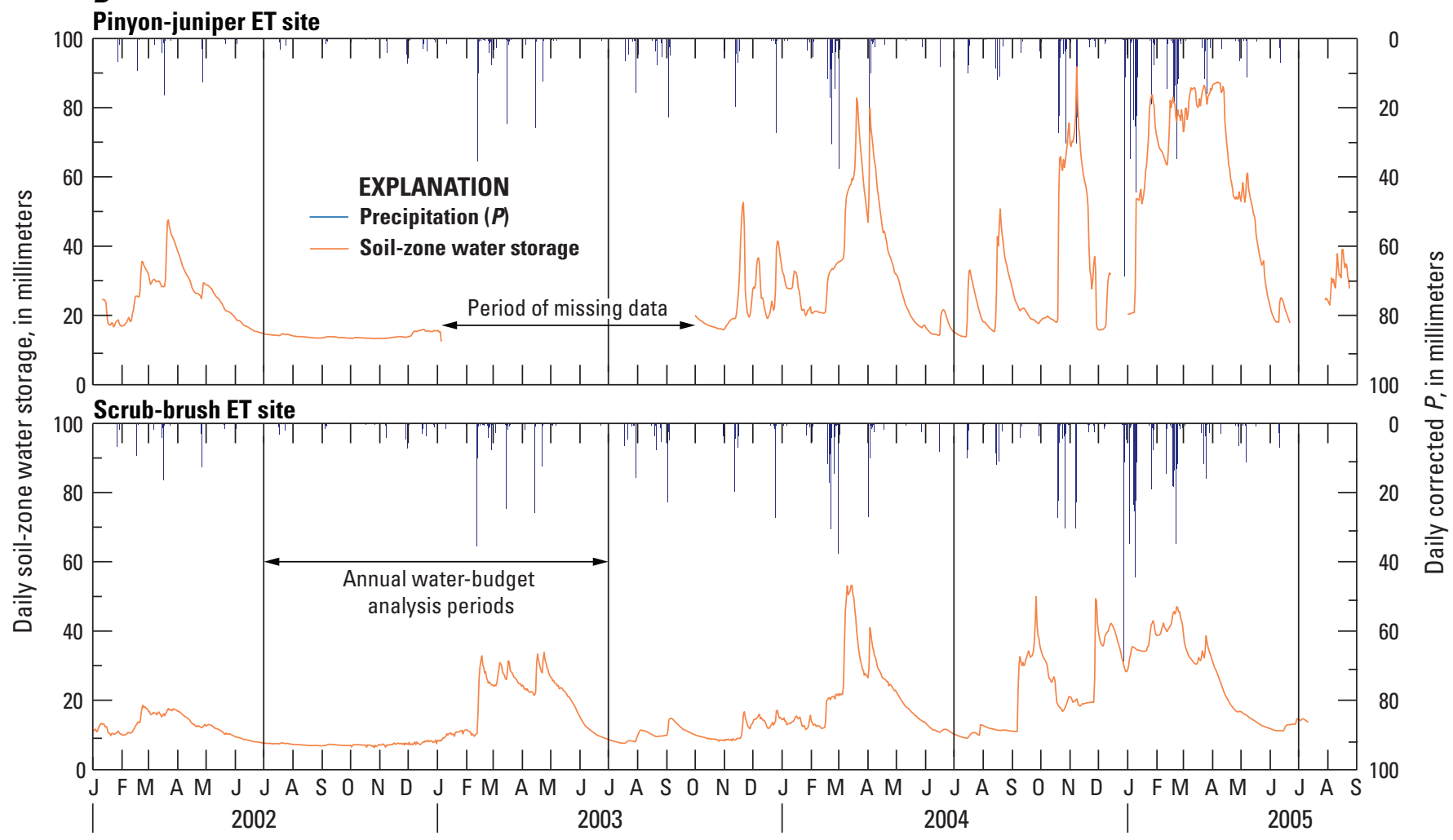

Figure 7. Daily corrected $(A)$ evapotranspiration $(E T)$ and $(B)$ precipitation and soil-zone water storage at the pinyonjuniper and scrub-brush ET sites, Rainier Mesa, Nevada National Security Site, Nevada, January 1, 2002, to August 24, 2005. 
Small seasonal variations between sites likely reflect differences in dominant vegetation species, phenological patterns, and landscape aspect at each site. The pinyon-juniper site is comprised of evergreen pines and is on a west-facing slope, whereas the scrub-brush site is comprised of droughtdeciduous shrubs and lies on a northwest-facing slope. Generally, snowmelt occurs earlier in the spring on westfacing and not north-facing slopes resulting in greater $E T$ and less infiltration at the pinyon-juniper site, and is delayed by tree shading resulting is less $E T$ and greater infiltration at the pinyon-juniper site.

The range in annual (July 1-June 30) $P$ during the study period presented an opportunity to evaluate $E T$ during historically below-average, near-average, and historically above-average precipitation years (fig. 6, tables 5 and 6). During the first year of the study, $P$ was $182 \mathrm{~mm}$ (about 50 percent of average) and $E T$ was $246 \mathrm{~mm}$ and $263 \mathrm{~mm}$ at the pinyon-juniper and scrub-brush $E T$ sites, respectively. This imbalance between $P$ and $E T$ indicates that an average of 27 percent of $E T$ at these sites was supplied by water stored from previous years. During the second year of the study, $P$ was $357 \mathrm{~mm}$ (about 98 percent of average), and $E T$ was $413 \mathrm{~mm}$ at the pinyon-juniper site and $387 \mathrm{~mm}$ at the scrub-brush site. Second-year results indicate that all $P$ was consumed by $E T$ during this near-average precipitation year. During the third year of the study, $P$ was $708 \mathrm{~mm}$ (about 194 percent of average), and $E T$ was $433 \mathrm{~mm}$ at the pinyonjuniper site. Annual ET during the third year was only $20 \mathrm{~mm}$ greater than the previous year even though $P$ was $351 \mathrm{~mm}$ greater, indicating that annual $E T$ during both years likely was near the maximum potential rate given the annual cycle of water availability.

\section{Root-Zone Water Storage Estimates}

Soil-zone water storage generally increased during autumn and winter in response to greater precipitation and lesser atmospheric-evaporative demands, decreased from spring to summer as stored water from snowmelt either percolated deeper or satisfied increasing $E T$ demand, and reached annual minima during summer (fig. 7B).

Annual changes in soil-zone water storage contributed negligibly to the water budget because analysis periods that begin and end during summer were selected specifically to minimize its effect on $\Delta S$ estimates.

Estimates of $\Delta S$ were negative during the first 2 years of the study (table 7). Negative $\Delta S$ values resulted during annual periods when some root-zone water stored during previous years was lost to ET. Computed soil-zone $S_{\max }$ values indicate that the soil zone has the capacity to yield the deficit (table 4); however, negligible amounts of water were stored or lost in the soil zone during selected annual water-budget analysis periods (fig. 7B). Thus, the primary source of water supporting atmospheric-evaporative demand was water stored in the fractured-bedrock zone (fig. 3). Annual $P$ for the 4 years preceding the study period ranged from 50 to 105 percent and averaged 80 percent $(292 \mathrm{~mm})$ of the annual mean $(365 \mathrm{~mm})$. Considering that about 8-30 percent of annual ET during the study period was supplied by root-zone water stored during previous years, the storage capacity of the bedrock must be sufficient to sustain vegetation through multiple below-average precipitation years. Estimates of weathered or fractured bedrock supplying most plant-available water when overlaid by a thin soil zone is supported by investigations of Jones and Graham (1993), Anderson and others (1995), and Hubbert and others (2001).

Table 7. Annual water budgets estimated for the pinyon-juniper and scrub-brush evapotranspiration sites, Rainier Mesa, Nevada National Security Site, Nevada, July 1, 2002-June 30, 2005.

[All values in millimeters. P: Precipitation. ET: Evapotranspiration. $\Delta S$ : Change in root-zone water storage. NI: Net infiltration]

\begin{tabular}{lccccc}
\hline $\begin{array}{c}\text { Evapotranspiration } \\
\text { site }\end{array}$ & Annual period & $\boldsymbol{P}$ & $\boldsymbol{E T}$ & $\Delta \boldsymbol{S}$ & $\boldsymbol{N I}$ \\
\hline Pinyon-juniper & 07-01-02 to 06-30-03 & 184 & 246 & -62 & 0 \\
& 07-01-03 to 06-30-04 & 357 & 413 & -56 & 0 \\
& 07-01-04 to 06-30-05 & 708 & 433 & 193 & 82 \\
\hline Scrub-brush & 07-01-02 to 06-30-03 & 184 & 263 & -79 & 0 \\
& 07-01-03 to 06-30-04 & 357 & 387 & -30 & 0 \\
\hline
\end{tabular}




\section{Net Infiltration Estimate}

Net infiltration occurred only during the third year (July 1, 2004, to June 30, 2005) of the study at the pinyon-juniper site, when $P$ exceeded $E T$ by $275 \mathrm{~mm}$. Water-balance model simulation results indicate that about 61 percent of annual $P$ was lost to $E T, 27$ percent was retained as bedrock-zone storage, and 12 percent $(82 \mathrm{~mm})$ became NI (table 7). The accumulated depletion of rootzone water-storage resulting from previous below-average precipitation years was replenished (fig. 8). Net infiltration processes were initiated in February 2005 after the root zone became fully saturated. Net infiltration occurred for only a brief period. By the end of the annual period (June 30, 2005), root-zone water storage declined by about $160 \mathrm{~mm}$ from full capacity, with about one-half the loss coming from the soil zone (fig. 7B) and one-half from the bedrock zone. Net infiltration also likely occurred during the third year at the scrub-brush site, but was not estimated because of insufficient data (fig. 7A). It should be noted that actual $N I$ timing could lag model simulated $N I$ timing because the water-balance model does not account for above-ground water storage (snowpack).

Model-simulated NI for the 3-year study period is reasonable when considered as part of a long-term annual average rate. Net infiltration occurred after the root zone was fully saturated (the bucket was full) during an excessively wet year. The water-balance model results indicated that net infiltration occurred in 2005, despite following 5 of 6 belowaverage precipitation years. Precipitation in 2005 was about 194 percent $(708 \mathrm{~mm}$ ) of the annual mean (fig. 6). If $N I$ is assumed to occur during every wet year, defined arbitrarily as greater than 150 percent of the annual mean, then NI would have occurred 6 times between 1960 and 2015, or about once every 9 years (fig. 6). If the $82 \mathrm{~mm}$ of simulated NI from 2005 is distributed over 9 years, then the annual $N I$ rate is about $9 \mathrm{~mm} / \mathrm{yr}$. This rate is within the previously estimated range of 5 to $50 \mathrm{~mm} / \mathrm{yr}$ (see section, "Hydrogeology of Rainier Mesa").

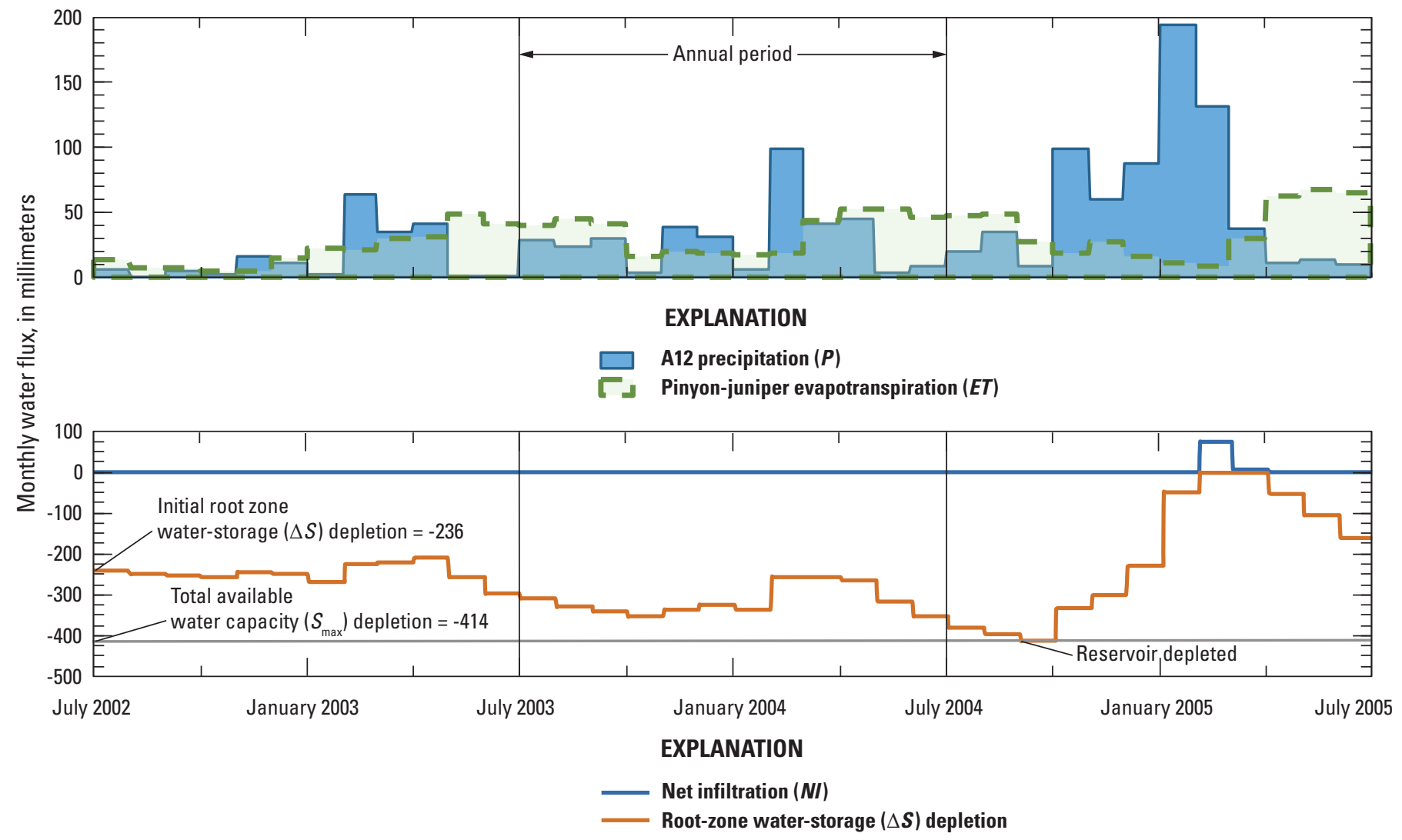

Figure 8. Water-balance model simulation results for pinyon-juniper evapotranspiration site, Rainier Mesa, Nevada National Security Site, 2002-05. 


\section{Limitations of Net Infiltration Estimate}

The accuracy of simulated NI presented in this report is limited primarily by the validity of assumptions made for the water-balance model. The water-balance model represents a simplified one-dimensional version of a complex three-dimensional system of soil and fractured bedrock water storage. Due to the inability to measure water content in the fractured bedrock, and lack of reported hydraulic properties, the available water capacity (table 4) was estimated based on literature values of root-zone depth and porosity. Model calibration based on multiple parameter estimates of rootzone depth, porosity, and root-zone storage at the beginning of the simulation period $\left(S_{b}\right)$ may lead to dissimilar model results. Thus, the calibrated model results are non-unique and additional hydraulic investigations of the bedrock near the soil zone are necessary to more accurately quantify $N I$.

As described in the section, "Model Calibration," model-simulated $N I$ is sensitive to $S_{b}$. The plausibility of $S_{b}$ $(178 \mathrm{~mm})$ was checked by adding this estimate to the total available water capacity $\left(S_{\max }\right)$ depletion $(-414 \mathrm{~mm})$, resulting in an initial $\Delta S$ depletion of $-236 \mathrm{~mm}$ (fig. 8). The initial $\Delta S$ depletion was then evaluated by applying the mean $\Delta S$ computed during the first 2 years of the study period $(-56 \mathrm{~mm}$, table 7) when precipitation was below average to the 4 years preceding the study period when precipitation also was below average. The result $(-59 \mathrm{~mm} \times 4=-236 \mathrm{~mm})$ indicates that the initial $\Delta S$ depletion of $-236 \mathrm{~mm}$ is reasonable.

\section{Conclusions}

The extreme range in annual precipitation during the 3-year study presented a rare opportunity to evaluate evapotranspiration (ET) and estimate net infiltration over a wide range of conditions. Annual (July-June) precipitation was the fourth lowest and second highest on record during the first and third years, with a near-average year in between.

Annual site-scale water-budget results indicate net infiltration was negligible during the below-average and average precipitation years, as ET exceeded precipitation at both sites. During these years, stored water was depleted from the fractured-bedrock of the root zone. During the wet third year, water storage in the bedrock of the root zone was replenished at the pinyon-juniper site and excess water storage became net infiltration.

The fractured bedrock of the root zone functions as a shallow reservoir. Water storage in the reservoir decreases during below-average (dry) precipitation years and increases during above-average (wet) precipitation years. Reservoir capacity is sufficient to meet atmospheric-evaporative demands and sustain vegetation through extended dry periods (1999-2004, for example), when limited precipitation likely caused a significant decline in storage. The resulting water-storage deficit probably precludes groundwater recharge until the root zone is fully saturated.

Percolation below the root zone (net infiltration) occurs during wet years once the reservoir is filled to capacity. The mechanisms controlling the rate of percolation below the root zone through the thick (300-500 m) unsaturated zone to the water table are poorly understood; however, water levels in selected wells near Rainier Mesa increased rapidly following the 2005 wet year as a result of an episodic recharge pulse. Therefore, it is reasonable that the water-level response was caused by the large increase in root-zone storage that was simulated during the third year of the study. The increase was sufficient to fill the bedrock reservoir and induce recharge through preferential fracture flow.

Plants on Rainier Mesa likely have adapted to using water at a rate that approaches the long-term average precipitation, relying on the shallow bedrock reservoir for water during dry years. It is assumed that the reservoir was depleted in September 2004, following 5 years of below-average precipitation and after the driest 2-year period on record. Annual ET rates at the end of the prolonged dry period (2003) were only 60 percent of ET rates during the wetter 2 years that followed. This anomalously low ET rate suggests that plants were stressed and the reservoir was low.

Only during excessively wet years is there sufficient precipitation to supply ET needs and also completely replenish the shallow reservoir. During these years, surplus precipitation can infiltrate below the root zone and recharge the deep water table. The long-term precipitation record at Rainier Mesa indicates that these extreme wet years are infrequent and may occur, on average, once every $5-10$ years. This is consistent with long-term water-level records in wells surrounding Rainier Mesa, which show recharge responses following wet years in 1995, 1998, and 2005 (Elliott and Fenelon, 2010).

\section{References Cited}

Anderson, M.A., Graham, R.C., Alyanakian, G.J., and Martynn, D.Z., 1995, Late summer water status of soils and weathered bedrock in a giant sequoia grove: Soil Science, v. 160 , no. 6. p. 415-422.

Belcher, W.R., 2004, Death Valley regional ground-water flow system, Nevada and California-Hydrogeologic framework and transient ground-water flow model: U.S. Geological Survey Scientific Investigations Report 2004-5205, 398 p., accessed July 2015 at https://pubs.usgs.gov/sir/2004/5205/.

Brutsaert, W.H., 1982, Evaporation into the atmosphere: Boston, Massachusetts, D. Reidel Publishing, 299 p.

Campbell, G.S., and Norman, J.M., 1998, An introduction to environmental biophysics ( $2 \mathrm{~d}$ ed.): New York, SpringerVerlag New York, Inc., 286 p. 
Clebsch, A., Jr., 1960, Ground water in the Oak Spring Formation and hydrologic effects of underground nuclear explosions at the Nevada Test Site: U.S. Geological Survey Open-File Report 60-27, 29 p.

Clebsch, Alfred, Jr., 1961, Tritium-age of ground water at the Nevada Test Site, Nye County Nevada (article 194), in U.S. Geological Survey, Short papers in the geologic and hydrologic sciences, articles 147-292: U.S. Geological Survey Professional Paper 424-C, p. C122-C125, accessed July 2015 at https://pubs.er.usgs.gov/publication/pp424C.

DeMeo, G.A., Flint, A.L., Laczniak, R.J., and Nylund, W.E., 2006, Micrometeorological and soil data for calculating evapotranspiration for Rainier Mesa, Nevada Test Site, Nevada, 2002-05: U.S. Geological Survey Open-File Report 2006-1312, 12 p., accessed July 2015 at https://pubs. usgs.gov/of/2006/1312/.

Doherty, J., 2010, PEST, Model-independent parameter estimation-User manual (5th ed., with slight additions): Brisbane, Australia, Watermark Numerical Computing, 279 p., accessed July 2015 at https://www.epa.gov/sites/ production/files/documents/PESTMAN.PDF.

Ebel, B.A., and Nimmo, J.R., 2009, Estimation of unsaturated zone travel times for Rainier Mesa and Shoshone Mountain, Nevada Test Site, Nevada using a source-responsive preferential-flow model: U.S. Geological Survey OpenFile Report 2009-1175, 74 p., https://pubs.usgs.gov/ of/2009/1175/.

Elliott, P.E., and Fenelon, J.M., 2010, Database of groundwater levels and hydrograph descriptions for the Nevada Test Site area, Nye County, Nevada (ver. 7.0, October 2016): U.S. Geological Survey Data Series 533, 16 p., accessed October 2016 at https://pubs.usgs.gov/ ds $/ 533 /$.

Fenelon, J.M., Laczniak, R.J., and Halford, K.J., 2008, Predevelopment water-level contours for aquifers in the Rainier Mesa and Shoshone Mountain area of the Nevada Test Site, Nye County, Nevada: U.S. Geological Survey Scientific Investigations Report 2008-5044, 38 p., accessed July 2015 at http://pubs.usgs.gov/sir/2008/5044/.

Fenelon, J.M., Sweetkind, D.S., and Laczniak, R.J., 2010, Groundwater flow systems at the Nevada Test Site, Nevada - A synthesis of potentiometric contours, hydrostratigraphy, and geologic structures: U.S. Geological Survey Professional Paper 1771, 54 p., 6 pls., accessed July 2015 at https://pubs.usgs.gov/pp/1771/.

Foken, T., 2008, The energy balance closure problemAn overview: Ecological Applications, v. 18, no. 6, p. 1,351-1,367.
Foken, T., Leuning, R., Oncley, S.R., Mauder, M., and Aubinet, M., 2012, Corrections and data quality control, in Aubinet, M., Vesala, T., and Papale, D., eds., Eddy covariance - A practical guide to measurement and data analysis: New York, Springer Atmospheric Sciences, 38 p.

Foxx, T.S., and Tierney, G.D., 1985, Rooting patterns in the Pinyon-Juniper Woodland, Los Alamos National Laboratory Report: New Mexico, Los Alamos National Laboratory, LA-UR 85-3819, 12 p., accessed August 2015 at http:// permalink.lanl.gov/object/tr?what=info:lanl-repo/lareport/ LA-UR-85-3819.

Freeze, R.A., and Cherry, J.A, 1979, Groundwater: Englewood Cliffs, New Jersey, Prentice-Hall, 604 p.

French, R.H., Jacobson, R.L., and Lyles, B.F., 1996, Threshold precipitation events and potential ground-water recharge: Journal of Hydraulic Engineering, v. 122, p. 573-578.

Garcia, C.A., Huntington, J.M., Buto, S.G., Moreo, M.T., Smith, J.L., and Andraski, B.J., 2015, Groundwater discharge by evapotranspiration, Dixie Valley, west-central Nevada, March 2009-September 2011: U.S. Geological Survey Professional Paper 1805, 90 p., accessed July 2015 at https://pubs.usgs.gov/pp/1805/.

Groisman, P., Ya, Koknaeva, V.V., Belokrylova, T.A., and Karl, T.R., 1991, Overcoming biases of precipitation measurement - A history of the USSR experience: Bulletin of the American Meteorological Society, v. 72, p. $1,725-1,732$.

Guswa, A.J., Celia, M.A., and Rodriguez-Iturbe, I., 2002, Models of soil moisture dynamics in ecohydrology-A comparative approach: Water Resources Research, v. 38, no. 9 , p. 1,166 .

Halford, K., Garcia, C.A., Fenelon, J., and Mirus, B., 2012, Advanced methods for modeling water-levels and estimating drawdowns with SeriesSEE, an Excel add-in: U.S. Geological Survey Techniques and Methods book 4, chap. F4, 28 p., accessed October 2014 at https://pubs.usgs. gov/tm/tm4-F4/.

Hansen, F.V, 1993, Surface roughness lengths: White Sands Missile Range, Army Research Laboratory Technical Report, ARL-TR-61, 22 p.

Healy, R.W., Winter, T.C., LaBaugh, J.W., and Franke, O.L., 2007, Water budgets - Foundations for effective waterresources and environmental management: U.S. Geological Survey Circular 1308, 90 p., accessed July 2015 at http:// pubs.usgs.gov/circ/2007/1308/. 
Hevesi, J.A., Flint, A.L., and Flint, L.E., 2003, Simulation of net infiltration and potential recharge using a distributedparameter watershed model of the Death Valley region, Nevada and California: U.S. Geological Survey WaterResources Investigation Report 03-4090, 161 p., accessed August 2015 at https://pubs.usgs.gov/wri/wri034090/.

Hubbert, K.R., Beyers, J.L., and Graham, R.C., 2001, Roles of weathered bedrock and soil in seasonal water relations of Pinus Jeffreyi and Arctostaphylos patula: Canadian Journal of Forestry, v. 31, p. 1,947-1,957.

Jacobson, R.L., Henne, M.S., and Hess, J.W., 1986, A reconnaissance investigation of hydrogeochemistry and hydrology of Rainier Mesa: Las Vegas, Nevada, Desert Research Institute Publication 45046, 64 p.

Jones, D.P., and Graham, R.C., 1993, Water-holding characteristics of weathered granitic rock in chaparral and forest ecosystems: Soil Science, v. 57, p. 256-261.

Kaimal, J.C., and Finnigan, J.J., 1994, Atmospheric boundary layer flows, their structure and measurement: New York, Oxford University Press, 289 p.

Larsen, L.W., and Peck, E.L., 1974, Accuracy of precipitation measurements for hydrologic modeling: Water Resources Research, v. 10, no. 4, p. 857-863.

Law, B.E., Loescher, H.W., Boden, T.A., Hargrove, W.W., and Hoffman, F.M., 2005, AmeriFlux site evaluation and recommendations for network enhancement: Oakridge National Laboratory, https://public.ornl.gov/ameriflux/ AmeriFluxSiteEvaluationWEB.pdf.

Leuning, R., van Gorsel, E., Massman, W.J., and Isaac, P.R., 2012, Reflections on the surface energy imbalance problem: Agricultural and Forest Meteorology, v. 156, p. 65-74.

Mirus, B.B., and Nimmo, J.R., 2013, Balancing practicality and hydrologic realism-A parsimonious approach for simulating rapid groundwater recharge via unsaturated-zone preferential flow: Water Resources Research, v. 49, p. 1,458-1,465, doi:10.1002/wrcr.20141.

Moore, C.J., 1986, Frequency response corrections for eddy correlation systems: Boundary-Layer Meteorology, v. 37, p. $17-35$.

Moreo, M.T., Laczniak, R.J., and Stannard, D.I., 2007, Evapotranspiration rate estimates of vegetation typical of ground-water discharge areas in the Basin and Range Carbonate-Rock aquifer system, Nevada and Utah, September 2005-August 2006: U.S. Geological Survey Scientific Investigations Report 2007-5078, 36 p., accessed July 2015 at https://pubs.er.usgs.gov/publication/ sir20075078.
Moreo, M.T., Senay, G.B., Flint, A.L., Damar, N.A., Laczniak, R.J., and Hurja, James, 2014, Hydroclimate of the Spring Mountains and Sheep Range, Clark County, Nevada: U.S. Geological Survey Scientific Investigations Report 2014-5142, 38 p., http://dx.doi.org/10.3133/sir20145142.

Moreo, M.T., and Swancar, A., 2013, Evaporation from Lake Mead, Nevada and Arizona, March 2010 through February 2012: U.S. Geological Survey Scientific Investigations Report 2013-5229, $40 \mathrm{p}$. [Also available at https://pubs.usgs.gov/sir/2013/5229/.]

National Oceanic and Atmospheric Administration, 2015, Air Resources Laboratory-Special Operations and Research Division precipitation data: National Oceanic and Atmospheric Administration, http://www.sord.nv.doe.gov/ PrecipitationPage.php.

Norris, A.E., Bentley, H.W., Cheng, S., Kubik, P.W., Sharma, P., and Gove, H.E., $1990,{ }^{36} \mathrm{Cl}$ studies of water movements deep within unsaturated tuffs: Nuclear Instruments and Methods in Physics Research, v. B52, p. $455-460$.

O'Reilly, A.M., 2004, A method for simulating transient ground-water recharge in deep water-table settings in central Florida by using a simple water-balance/transferfunction model: U.S. Geological Survey Scientific Investigations Report 2004-5195, 49 p. [Also available at https://pubs.usgs.gov/sir/2004/5195/.]

Priestley, C.H.B., and Taylor, R.J., 1972, On the assessment of surface heat flux and evaporation using large-scale parameters: Monthly Weather Review, v. 100, p. 81-92.

Rodriguez-Iturbe, I., Porporato, A., Ridolfi, L., Isham, V., and Cox, D.R., 1999, Probabilistic modelling of water balance at a point-The role of climate, soil and vegetation: Proceedings of the Royal Society of London A, v. 455, p. 3,789-3,805.

Russell, C.E., 1987, Hydrogeologic investigations of flow in fractured tuffs, Rainier Mesa, Nevada Test Site: Las Vegas, University of Nevada, M.S. thesis, p. 180.

Russell, C.E., and Minor, T., 2002, Reconnaissance estimates of recharge based on an elevation dependent chloride massbalance approach: U.S. Department of Energy, Publication Number 45164, DOE/NV/11508- 37, 66 p.

Salter, P.J., and Williams, J.B., 1965, The influence of texture on the moisture characteristics of Soils-I-A critical comparison of techniques for determining the availablewater capacity and moisture characteristic curve of a soil: Journal of Soil Science, v. 16, no. 1, 15 p. 
Savard, C.S., 1998, Estimated ground-water recharge from streamflow in Fortymile Wash near Yucca Mountain, Nevada: Water-Resources Investigation Report 97-4273. 29 p., https://pubs.usgs.gov/wri/1997/4273/report.pdf.

Schotanus, P., Nieuwstadt, F.T.M., and de Bruin, H.A.R., 1983, Temperature measurement with a sonic anemometer and its application to heat and moisture fluxes: BoundaryLayer Meteorology, v. 50, p. 81-93.

Shuttleworth, W.K, 1993, Evaporation, in Maidment, D.R., ed., Handbook of hydrology: New York, McGraw-Hill, $10 \mathrm{p}$.

Smith, D.W., Moreo, M.T., Garcia, C.A., Halford, K.J., and Fenelon, J.M., 2017, Supplemental data from-A process to estimate net infiltration using a site-scale water-budget approach, Rainier Mesa, Nevada National Security Site, 2002-05: U.S. Geological Survey data release, https://doi. org/10.5066/F7222SP5.

Soule, D.A., 2006, Climatology of the Nevada Test Site: Las Vegas, Nevada, Department of Energy Special Operations and Research Division, SORD Technical Memorandum SORD 2006-03, 165 p., http://www.sord.nv.doe.gov/ documents/Climatology_of_The_Nevada_Test_Site.Soule. pdf.

Stannard, D.I., Gannett, M.W., Polette, D.J., Cameron, J.M., Waibel, M.S., and Spears, J.M., 2013, Evapotranspiration from marsh and open-water sites at Upper Klamath Lake, Oregon, 2008-2010: U.S. Geological Survey Scientific Investigations Report 2013-5014, 66 p. [Also available at http://pubs.usgs.gov/sir/2013/5014/.]

Stoller-Navarro Joint Venture, 2008, Phase I hydrologic data for the groundwater flow and contaminant transport model of corrective action unit 99: Las Vegas, Nevada, Rainier Mesa/Shoshone Mountain, Nevada Test Site, Nye County, Nevada, Rev. 1, S-N/99205-103.

Swinbank, W.C., 1951, The measurement of vertical transfer of heat and water vapor by eddies in the lower atmosphere: Journal of Meteorology, v. 8, no. 3, p. 135-145.

Tanner, B.D., and Greene, J.P., 1989, Measurement of sensible heat and water-vapor fluxes using eddy-correlation methods: Final report prepared for U.S. Army Dugway Proving Grounds, U.S. Army, Dugway, Utah, 17 p.
Thordarson, W., 1965, Perched ground water in zeolitizedbedded tuff, Rainier Mesa and vicinity, Nevada Test Site, Nevada: U.S. Geological Survey Open-File Report 66-130, $90 \mathrm{p}$. [Also available at http://pubs.er.usgs.gov/publication/ ofr66130.]

Twine, T.E., Kustas, W.P., Norman, J.M., Cook, D.R., Houser, P.R., Meyers, T.P., Prueger, J.H., Starks, P.J., and Wesely, M.L., 2000, Correcting eddy-covariance flux underestimates over a grassland: Agricultural and Forest Meteorology, v. 103 , p. 279-300.

U.S. Department of Agriculture, 2005, National soil survey handbook: U.S. Department of Agriculture, part 618, section 618.6, http://soils.usda.gov/technical/handbook/ Salter.

U.S. Department of Energy, 2004, Corrective Action Investigation Plan for Corrective Action Unit 99-Rainier Mesa/Shoshone Mountain, Nevada Test Site, Nevada: U.S. Department of Energy, DOE/NV-1031, 320 p.

U.S. Department of Energy, 2015, United States nuclear tests, July 1945 through September 1992: U.S. Department of Energy Report DOE/NV—209 REV 16, 129 p.

Walker, G.R., Zhang, Lu, Ellis, T.W., Hatton, T.J., and Petheram, Cuan, 2002, Estimating impacts of changed land use on recharge - Review of modeling and other approaches appropriate for management of dryland salinity: Hydrogeology Journal, v. 10, no. 1, p. 68-90.

Webb, E.K., Pearman, G.I., and Leuning, R., 1980, Correction of flux measurements for density effects due to heat and water vapour transfer: Quarterly Journal of the Royal Meteorological Society, v. 106, p. 85-100.

Wilson, K., Goldstein, A., Falge, E., Aubinet, M., Baldocchi, D., Berbigier, P., Bernhofer, C., Ceulemans, R., Dolman, H., Field, C., Grelle, A., Ibrom, A., Law, B.E., Kowalski, A., Meyers, T., Moncrieff, J., Monson, R., Oechel, W., Tenhunen, J., Valentini, R., and Verma, S., 2002, Energy balance closure at FLUXNET sites: Agricultural and Forest Meteorology, v. 113, nos. 1-4, p. 223-243.

Yang, D., Goodison, B.E., Metcalfe, J.R., Golubev, V.S., Bates, R., Pangburn, T., and Hanson, C.L., 1996, Accuracy of NWS 8" standard nonrecording precipitation gaugeResults and application of WMO intercomparison: Journal of Atmospheric and Oceanic Technology, v. 15, p. 54-68. 
Publishing support provided by the U.S. Geological Survey

Science Publishing Network, Tacoma Publishing Service Center

For more information concerning the research in this report, contact the Director, Nevada Water Science Center

U.S. Geological Survey

2730 N. Deer Run Rd.

Carson City, Nevada 89701

https://nevada.usgs.gov 
